\title{
Does energy efficiency matter to real estate-consumers? Survey evidence on willingness to pay from a cost-optimal analysis in the context of a developing country
}

\author{
Felipe Encinas $^{1, a, b, c}$, Carlos Marmolejo ${ }^{\mathrm{d}}$, Francisco Sánchez de la Flor ${ }^{\mathrm{e}}$, Carlos Aguirre ${ }^{\mathrm{f}}$ \\ ${ }^{a}$ Escuela de Arquitectura; Facultad de Arquitectura, Diseño y Estudios Urbanos; Pontificia Universidad Católica \\ de Chile. El Comendador 1916, Providencia, Santiago, Chile. felipe.encinas@uc.cl \\ ${ }^{\mathrm{b}}$ Centre for Sustainable Urban Development (CEDEUS) \\ ${ }^{c}$ UC Energy Research Centre (CE-UC) \\ ${ }^{\mathrm{d}}$ Centre de Política de Sòl i Valoracions (CPSV); Universitat Politècnica de Catalunya - BarcelonaTech. \\ Av. Diagonal 649, 08028 Barcelona, Spain. upc.carlos.marmolejo@gmail.com \\ e Departamento Máquinas y Motores Térmicos; Escuela Superior de Ingeniería; Universidad de Cádiz. \\ Av. Universidad de Cádiz 10, 11519 Puerto Real, Cádiz, Spain. francisco.flor@uca.es
}

${ }^{\mathrm{f}}$ Escuela de Construcción; Universidad de las Américas. Av. Manuel Montt 948, Providencia, Santiago, Chile. caguirre@udla.cl

\begin{abstract}
In most countries, energy efficiency at the residential level has been largely delegated to the dynamics of realestate markets after setting a minimum level. This regulatory definition is in certain cases supplemented by energy performance certificates, such as in the case of the European Union. This approach is based on the understanding that avoided energy-consumption costs positively affect the willingness to pay for them, thus leading to higher prices capable of offsetting production costs and thereby encouraging developers. The case of the private housing market in Santiago de Chile was selected as a reference for a developing country in which energy performance certificates, although they exist as an instrument, are not required to be applied in property transactions. However, unlike most of the research performed in developed countries, it is difficult to analyse price formation using methods based on observed preferences in areas in which there are few energy-certified buildings. Using the technique of contingent valuation, such as the method based on stated preferences, enables one to overcome this difficulty. This article investigates willingness to pay for improvements in the energy efficiency of buyers for new homes based on a representative investment/operation cost analysis. This approach has been addressed to open the debate on the convenience of modify the national construction code and rethink the energy certification scheme as well as an exploratory study to undercover further research lines to support the aforementioned debate. The results suggests that there is a number of potential home buyers ready to pay for energy efficiency when they are informed on the cost savings associated to structural modifications and the cost of providing such improvements and such willingness to pay is not monolithic across the respondents, but seems to be influenced by the education level plausibly associated to the purchase power.
\end{abstract}

Keywords: energy efficiency; real estate; willingness to pay; cost-optimal analysis

\footnotetext{
${ }^{1}$ Corresponding autor at: Escuela de Arquitectura, Facultad de Arquitectura, Diseño y Estudios Urbanos, Pontificia Universidad Católica de Chile, El Comendador 1916, Providencia, Santiago, Chile. Tel.: +56 (0)2 354 7721. E-mail address: felipe.encinas@uc.cl (F. Encinas).
} 


\section{Introduction}

In most countries, energy efficiency at the residential level has been largely delegated to the dynamics of real-estate markets after setting a minimum level. This regulatory definition, which can be viewed from a prescriptive perspective (in relation to demands due to the building element, for example, in terms of the thermal transmittance of walls or ceilings) or from a performance perspective (associated with performance indicators, such as heating demand or consumption), is in certain cases supplemented by the mandatory inclusion of energy certificates (Pérez-Lombard et al., 2009). Such certificates typically assume the form of a rating (e.g., using letters), which appears on labels.

However, the liberalized market does not deliver an optimum for the energy efficiency of homes. In fact, there is an energy efficiency gap that slows the diffusion of energy efficient products below the socially optimal rate. Gillingham and Palmer (2014) have stressed some causes for such gap: [1] the information is imperfect for some of the actors participating in the market rendering an information asymmetry between buyers and sellers (i.e. in some cases, such as in the new housing, the sellers may have better information regarding energy efficiency than buyers do); [2] investment decisions and savings are made by different agents, buyers or tenants, and therefore are subject to their perception of the impacts of energy efficiency, and the decision of one may affect very differently the other; [3] in general more efficient technologies imply a higher upfront cost that compassed with credit limitations results in a lower consumption of such technologies, especially when "green credits" are not present such as the case of Chile; [4] the users of the dwellings have a learning curve for the use of the dwelling and the elements of energy efficiency, generating changes in the assumptions foreseen in the evaluation ex before; and [5] government regulations in the energy market results in prices that differ from marginal costs. Additionally, to the said causes coming from the neoclassical theory, Gillingham et al. (2009) point out other coming from the behavioural economics: [1] non-standard preferences, [2] non-standard beliefs and 3) non-standard decision makings. In such logic energy labelling policy can help to reduce the gap in some of its causes: [1] reduce information asymmetry by providing relevant information of possible energy savings and environmental protection to consumers; [2] standardize the format in which energy efficiency information is presented reducing in that way the framing choice bias (i.e non-standard decision making); and [3] when accompanied by a communication strategy, it may help to train consumers on the benefits of energy efficiency. Allcott and Taubinsky (2015) review some plausible benefits for information provision: [1] biased beliefs (i.e. consumers know that efficient homes use less energy but they mis-estimate the cost savings); [2] exogenous inattention to energy as a "shrouded" add-on cost; [3] costly information acquirement (i.e. consumers incurs a 
cost to learn on energy efficiency and when they have not access to such information assume the same efficiency for different homes); and [4] noisy and costly thinking (i.e. consumers have a broad idea of the true value of energy efficiency, but thinking allows a more precise quantification).

In this line, the European Energy Performance of Buildings Directive (Official Journal of the European Union, 2010, 2003) introduced universal energy labels termed Energy Performance Certificates (EPCs) in the European property market. This policy aims to provide property transactions with energy transparency to encourage more informed buying or leasing decisions. Thus, the policy supports the construction of buildings with higher energy-efficiency standards through indirect promotion. The policy is based on the understanding that avoided energy-consumption costs positively affect the willingness to pay (WTP) for such costs, thus leading to higher prices capable of offsetting production costs and thereby encouraging developers.

Consequently, according to market logic, it is expected that housing developments with higher levels of energy efficiency receive a market premium with the understanding that the marginal benefits are equivalent to the marginal costs for thermal envelope improvements and/or more efficient systems. The pioneering research of Dinan and Miranowsky (1989) revealed that improvements in energy efficiency applied in the real-estate market in Des Moines, Iowa, equalled a reduction in energy consumption of 1 USD (while maintaining the house at a comfortable temperature of $18^{\circ} \mathrm{C}$ ), which represented a market premium of 11.63 USD in price. In recent years, subsequent studies have addressed the impact of energy labelling on real-estate prices, such as Energy Star certification (Bruegge et al., 2015; Kahn and Kok, 2013), the previously mentioned EPCs (de Ayala et al., 2016; Fuerst et al., 2016, 2013a, 2013b; Gelegenis et al., 2014; Marmolejo-Duarte, 2016) and others (Fuerst and Shimizu, 2016), by identifying different levels in the market premiums associated with better-rated homes. A study by Bio Intelligence Service et al. (2013) describes the empirical foundation of the EPC programme and the pricing system. The study was commissioned by the European Community for the purpose of an overall assessment of the EPBD. The study reveals that the effect of each of the EPC label levels (expressed in letters) on the price offer varies. The effect ranges from $0.4 \%$ in Oxford to $11 \%$ in Vienna; it is $4.3 \%$ in Marseille, $3.2 \%$ in Lille and 2.9\% in Brussels. Other studies have not found a linear or continuous relationship between the EPC rating and prices. Hyland et al. (2013) found for Ireland that the impact of one EPC level on a two-bedroom apartment equalled an increase of $2.3 \%$, while for three-bedroom and four- to five-bedroom homes, the increase was lower: $1.7 \%$ and $1.6 \%$, respectively. A study on 300,000 homes in England found that the EPC's greatest impact was on row houses and that the effect on apartments was higher than on isolated houses (Fuerst et al., 
2015). This finding might suggest that the potential savings in energy consumption is more important for less expensive housing occupied by persons of lower income.

However, unlike most of the research performed in the previously noted developed countries, it is difficult to analyse price formation using methods based on observed preferences (as in the econometric models used in these studies) in areas in which there are few energy-certified buildings. Using the technique of contingent valuation, despite the controversies related to the "hypothetical-bias" further discussed, such as the method based on stated preferences, enables one to overcome this difficulty in environments in which the associated public policy is recent (Marmolejo-Duarte et al., 2017). The case of the private housing market in Santiago de Chile ${ }^{2}$ was selected as a reference for a developing country in which energy performance certificates, although they exist as an instrument, are not required to be applied in property transactions. Interestingly, less than $1 \%$ of new completed private homes do exhibit energy certificates, which in turns opens the question on whether such astonishing absences is produced by buyers' unwillingness to make an extra payment for efficient houses.

This article investigates WTP for improvements in the energy efficiency of buyers for new homes in comparison to a representative investment/operation cost analysis from the real-estate market of Santiago de Chile. This approach has been addressed to open the debate on the convenience of modify the national construction code and rethink the energy certification scheme as well as an exploratory study to undercover further research lines to support the aforementioned debate. Both processes have now been indefinitely postponed because of the uncertainty related to the lack of knowledge about the demand preferences to compensate the additional costs from energy efficient improvements. In this sense, given that [1] WTP was evaluated in real consumers who were seeking to buy houses; and [2] improvements in energy efficiency were proposed based on a cost-optimal approximation applied to representative cases of the real estate market and considering all economic factors, it is expected that these results can identify a potential demand for homes with high energy-performance standards in the Santiago real-estate supply. While this demand would be associated with certain niche markets for higher-priced homes, it may indicate a need for a real-estate product that - at least in mass production - is currently lacking.

Finally, it is worth nothing that this unexplored topic is relevant for the Latin-American region, since Chile has become a benchmark for such region in terms of the early adoption of regulations that affect the energy

\footnotetext{
${ }^{2}$ Santiago, as the capital city of the country, has a great importance, since it concentrates - at the same time - the $45 \%$ of the population (CChC, 2017) and 57\% of the housing supply from the national real estate market (Rioseco and Tesser, 2017). It typically corresponds to a warm temperate climate with long dry season from 8 to 7 months (Csb according to the Köppen-Geiger classification), which can also be defined as a Mediterranean climate (Encinas and Aguirre, 2017).
} 
performance of dwellings. In addition, the country has been experiencing accelerated urbanisation and a realestate boom for more than a decade, which other countries, such as Peru and Colombia, are now experiencing.

\section{Public policies on the energy efficiency of homes in Chile}

The housing market in Chile has a low government presence, which was defined by López-Morales, Gasic and Meza (2012) as "pro-business urban planning," and according to Savage, Warde and Ward (2003), "It implies not only that the State is active in the production of favourable market conditions but also that the market operates within the State with its logic of competitiveness and its dialectic of volatility versus spatial anchor of capital.” The new National Urban Policy (MINVU, 2014a) includes elements of city management, however, its analysis reveals that the housing market is largely unregulated. The externalities characteristics of new urban developments are furnished to developers to profit from with little regulation. In this logic, the liberalisation of Chilean markets, particularly the real-estate market, has made the State reactive in its efforts to solve problems. Notwithstanding this situation, Chile was one of the first Latin American countries to adopt a mandatory energy regulation for houses. In 2000, the so-called Thermal Regulation established requirements regarding the maximum permissible thermal transmittance for roofing. The 2007 update added thermal conditioning requirements for roofs, perimeter walls and ventilated floors throughout the country (MINVU, 2016a). According to the World Bank Working Paper No. 204, Chile - along to Mexico - seems to be the most proactive country with respect to building energy efficiency (Liu et al., 2010). However, according to the same source, this regulation may be considered "relatively lenient in comparison to international state-of-art". The OECD has also noted the matter and strongly recommended that the country move forward on the best standards for thermal envelopes (Caldera Sánchez, 2012). In general, the national experts have been valued these standards as initial definition but as deficient in terms of their effective contribution to housing energy efficiency (Bustamante et al., 2009a, 2009b; Celis et al., 2012; Collados and Armijo, 2008), since has also not been updated in ten years. This limitations can be understood by the fact that are intended to address "no more than the minimum conditions for the average household, or to act as palliative solutions for highly inadequate dwellings" (Bunster and Noguchi, 2015). In this sense, the international commitments that the country has assumed encouraged a 2014 proposal to update national thermal regulations (MINVU, 2014b), which represents a considerable improvement over the previous standards. In the case of Santiago, the maximum thermal transmittance for walls changed from $1.9 \mathrm{~W} / \mathrm{m}^{2} \mathrm{~K}$ to $0.6 \mathrm{~W} / \mathrm{m}^{2} \mathrm{~K}$. In terms of construction, this change means switching from a brick masonry wall without thermal insulation to a wall that incorporates at least $50 \mathrm{~mm}$ of such insulation (assuming an expanded 
polystyrene foam density of $20 \mathrm{~kg} / \mathrm{m}^{3}$ ). The rationale for this change was based on the need to improve the atmospheric environmental conditions of the main cities in the central, south-central and southern regions of the country.. In effect, through a socio economic impact assessment, the effects of the improved thermal envelope standards were valued considering the costs of heating-fuel consumption and healthcare that could be avoided by reducing particulate matter emissions from residential heating systems (Bustamante, 2013). Accordingly, a thermal insulation thickness of $50 \mathrm{~mm}$ was established, which corresponds to the highest net present value (NPV) obtained considering impacts on health. However, this "social optimum" increases thermal insulation thickness to $80 \mathrm{~mm}$ if the most severe health impacts are considered. Finally, the proposed upgrade was incorporated as a reference for the Standards of Sustainable Construction (MINVU, 2016b) - which corresponds to a good practices guide - but the mandatory application as part of the General Urbanism and Construction Ordinance has been indefinitely postponed.

At the same time, the home energy rating has been implemented in Chile since 2013. It is an instrument that assesses the energy efficiency of a house based on its consumption of hot water, lighting and heating. The rating can be applied as a "pre-qualification," i.e., for a project (with an approved building permit) with a provisional character, or as a "rating," which assumes that the house is already built (with final municipal approval obtained). In both cases, a label is awarded as a result of a process that at least in form is similar to that of the $\mathrm{EPC}$, i.e., a letter ranking in a range from A to G (from most to least efficient), whereby E represents the construction standard of the thermal regulations currently in force.

Originally, compulsory implementation of the system was to gradually begin in 2016 (DITEC, 2015). However, this plan was indefinitely postponed. Thus, today, a voluntary standard is available, though its adoption by the market has been low. In fact, in terms of the final grade only $5.5 \%$ of these dwellings are in the private market. which in absolute terms translates into 594 homes across Chile since the system's introduction in 2013 until January 2017 (Table 1) (Ministerio de Vivienda y Urbanismo, 2017). This figure is absolutely marginal compared to the total stock of the real-estate market, which at the national level fluctuated between 67,781 and 101,398 units for the same period (CChC, 2017). 
Table 1

Number of pre-rated and rated homes in the country as of January 2017 based on the home energy rating tool according to the letter obtained in the labelling. Percentage obtained with respect to all types of housing per column.

\begin{tabular}{|c|c|c|c|c|c|c|c|c|c|}
\hline & & \multicolumn{2}{|c|}{ Labels $A$ and $B$} & \multicolumn{2}{|c|}{ Labels C and D } & \multicolumn{2}{|c|}{ Labels $E, F$ and $G$} & \multicolumn{2}{|c|}{ Total } \\
\hline & & $\mathrm{N}$ & $\%$ & $\mathrm{~N}$ & $\%$ & $\mathrm{~N}$ & $\%$ & $\mathrm{~N}$ & $\%$ \\
\hline \multirow{2}{*}{ Private housing } & Pre-rated & 1047 & $95.4 \%$ & 1900 & $20.4 \%$ & 998 & $12.7 \%$ & 3945 & $21.6 \%$ \\
\hline & Rated & 94 & $81.0 \%$ & 402 & $9.0 \%$ & 98 & $1.6 \%$ & 594 & $5.5 \%$ \\
\hline \multirow{2}{*}{$\begin{array}{l}\text { Government } \\
\text { housing }\end{array}$} & Pre-rated & 50 & $4.6 \%$ & 7083 & $75.9 \%$ & 6626 & $84.6 \%$ & 13759 & $75.4 \%$ \\
\hline & Rated & 22 & $19.0 \%$ & 4028 & $90.2 \%$ & 5974 & $96.3 \%$ & 10024 & $93.0 \%$ \\
\hline \multirow{2}{*}{ Mixed housing } & Pre-rated & 1 & $0.1 \%$ & 344 & $3.7 \%$ & 205 & $2.6 \%$ & 550 & $3.0 \%$ \\
\hline & Rated & 0 & $0.0 \%$ & 34 & $0.8 \%$ & 132 & $2.1 \%$ & 166 & $1.5 \%$ \\
\hline \multirow{2}{*}{ Total } & Pre-rated & 1098 & $100.0 \%$ & 9327 & $100.0 \%$ & 7829 & $100.0 \%$ & 18254 & $100.0 \%$ \\
\hline & Rated & 116 & $100.0 \%$ & 4464 & $100.0 \%$ & 6204 & $100.0 \%$ & 10784 & $100.0 \%$ \\
\hline
\end{tabular}

Source: Ministerio de Vivienda y Urbanismo (2017)

Because the domestic market has not widely adopted an objective tool, such as an energy rating, to inform consumers regarding energy efficiency in real-estate transactions ${ }^{4}$, the approach chosen to communicate the competitive advantages of energy efficiency and sustainability has been through their attributes (Encinas et al., 2018). Nonetheless, such marketing-advertisement of "sustainability attributes" is spurious since it does not inform in a synthetic way the energy implications of their presence, expressed both in economic (i.e. potential energy savings) and environmental (i.e. greenhouse emissions) terms as some energy label do. In turn, such approach does not contribute to shed light to the energy transparency necessary, although incomplete, to foster energy-rational preferences from the demand side. These attributes are understood as those features of the realestate product that can generate a differentiation in housing while contributing to its construction value. In turn, this value can be defined as the perception of consumers with respect to a particular asset, thereby making it possible to establish their WTP for that value (Encinas, 2012). As defined by Lancaster (1966), housing is desired not in and of itself but as the sum of each real estate product's features, where the most important have a greater impact on determining preferences and choices (Jansen, 2011), according to the compensatory logic of trade-offs.

In a preliminary approach to the attributes of energy efficiency and sustainability in the residential market in Santiago, the position of these attributes in the advertising of real-estate offers was evaluated. To this end, all

\footnotetext{
${ }^{4}$ Although a number of private or public energy-certification systems (e.g., LEED or Passivhaus) have appeared in the national market, their positioning on a general level remains incipient. For example, of all private offers published at portalinmobiliario.com, only $1.6 \%$ declared possessing such certification (Encinas and Aguirre, 2017)
} 
listings of new projects at Portalinmobiliario.com ${ }^{5}$ were studied for the period 2007-2014 (a total of 3422 apartment buildings and 718 house complexes) (Encinas et al., 2016). Among the obtained results (Figure 1), it is noteworthy that the presence of double-glazed windows increased from 5\% in 2007 to $29 \%$ in 2014 with respect to the total supply of apartments. In the case of houses, it is interesting to observe how the increase in the thickness of thermal insulation as a selling point for houses increased from $4 \%$ to $10 \%$ during the same period. For both types of housing, the impact of the implementation of Law 20365 (which corresponds to a tax exemption for solar thermal systems; in force since 2010 for a period of three years) on the supply is evident, displaying a considerable increase that peaked at approximately $5 \%$ for households and $12 \%$ for apartments in 2013, followed by a decrease. In addition, one can generally observe how the attributes of energy efficiency are presented as isolated elements, regardless of the energy performance as a complete system in the sense proposed by the European Directive and their energy certificates or the national energy rating.

In sum, it seems there is growing interest on "sustainability attributes" on the Chilean real-estate advertising, yet whether such presence is a response from developers to an increased interest of demand remains an open question, which is explored in this paper from the perspective of willingness to pay, as it is next explained.
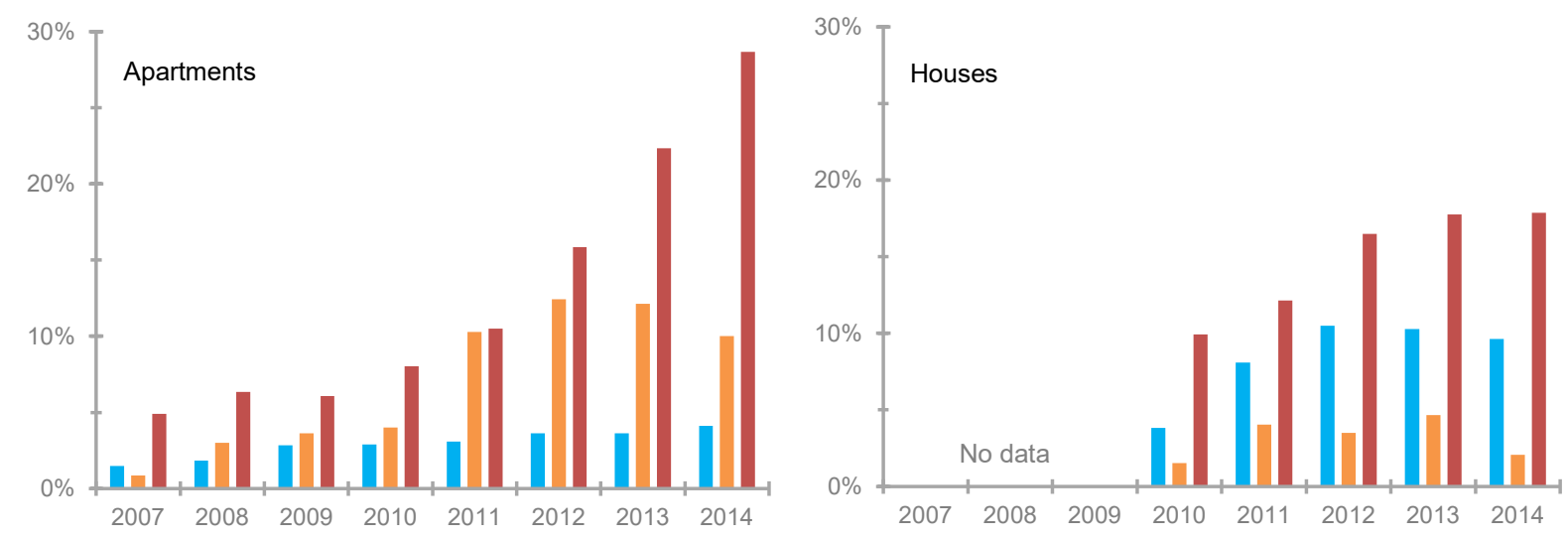

Increased thermal insulation

Solar thermal collectors

Double-glazed windows

Source: Encinas et al.(2016)

(Note: 2-column fitting image)

Figure 1. Presence of energy-efficiency attributes in new dwellings with respect to the total supply in Santiago by typology

\footnotetext{
${ }^{5}$ Portalinmobiliario.com is the most important search portal in the country for the sale and lease of properties. It is part of Mercado Libre, company with operations in many countries of the region, such as Argentina, Bolivia, Brazil, Chile, Colombia, Costa Rica, Ecuador, Mexico, Paraguay, Peru, Uruguay and Venezuela.
} 


\section{Methods}

\subsection{Definition of house typologies}

In real-estate analysis, submarkets are usually defined according to segmentation in terms of price ranges and useful surface area. However, this type of approach does not consider that real-estate products can compensate for the lack of specific attributes with other attributes. This article proposes a multidimensional approach based on cluster analysis from Encinas and De Herde (2013), as was applied in the studies of Bourassa et al. (1999) and Wu and Sharma (2012) to housing submarkets. For our sample, we used the Portalinmobiliario.com database for the period 2010-2013, corresponding 718 housing units. We decided to study the private house market in Santiago (as opposed to the city's apartment market) because houses have a larger usable surface area and exposed envelope area. Therefore, they consume more energy and are thus more sensitive to energy-efficiency improvements (Bustamante et al., 2009b). Using this methodology, three house typologies were selected to represent the complete range of areas and prices of the real-estate market, as it presented in Table 2 . Finally, to generate a model using a bottom-up approach in the sense proposed by Kavgic et al. (2010), each building type consisted of a house statistically representative of the supply as selected at the online search portal (Portalinmobiliario.com, 2017) and considering the 50th percentile for the continuous variables of offer price and constructed area. Figures 2, 3 and 4 show the general planimetry and an isometric view of representative houses of the three typologies. It should be noted that that this procedure is very important in the context of the study, since it generates a representative approach of the private housing stock. In this sense, the three selected typologies represent $74 \%$ of the total of houses in the real estate market of Santiago.

Table 2

Values obtained for the 25th, 50th and 75th percentiles of the continuous variables for the selected house typologies

\begin{tabular}{|c|c|c|c|c|c|c|c|c|}
\hline \multicolumn{3}{|c|}{ House typology } & \multicolumn{3}{|c|}{ Offer price } & \multicolumn{3}{|c|}{ Constructed area $\left[\mathrm{m}^{2}\right]$} \\
\hline & $\mathrm{N}$ & $\%$ & P25 & P50 & P75 & $\mathrm{P} 25$ & $\mathrm{P} 50$ & P75 \\
\hline 1 & 436 & $61 \%$ & $58000 €$ & $74000 €$ & $96000 €$ & 68.5 & 80.9 & 98.5 \\
\hline 2 & 37 & $5 \%$ & $98000 €$ & $153000 €$ & $247000 €$ & 87.5 & 122.8 & 138.1 \\
\hline 3 & 59 & $8 \%$ & $384000 €$ & $493000 €$ & $571000 €$ & 205.0 & 238.8 & 270.3 \\
\hline Total & 532 & $74 \%$ & & & & & & \\
\hline
\end{tabular}




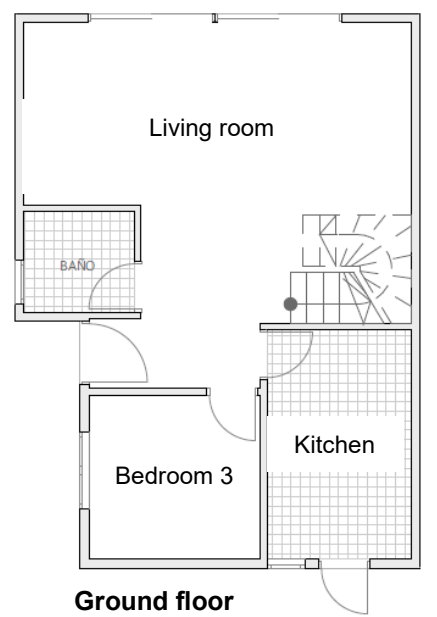

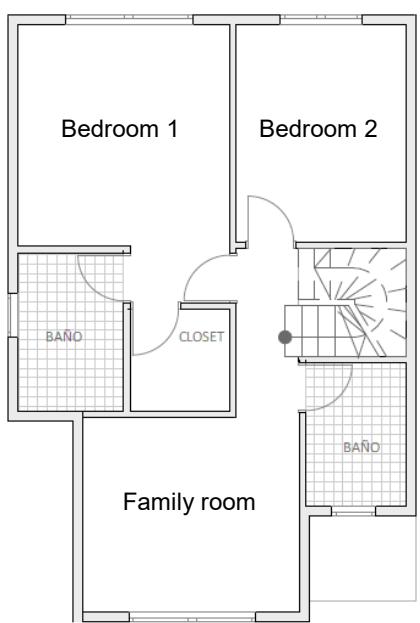

First floor

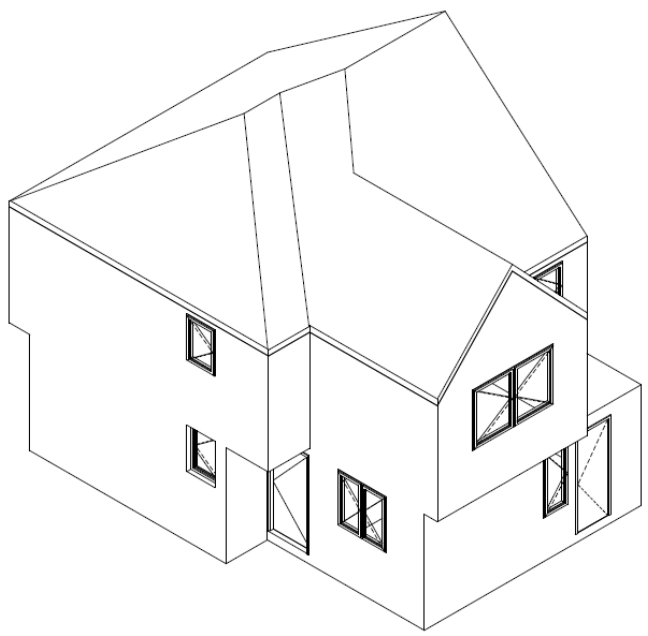

Isometric view $\prod_{0}^{\square} \quad \prod_{1} \mathrm{~m}$

(Note: 2-column fitting image)

Figure 2. Floor plans and isometric view of the representative house for type 1

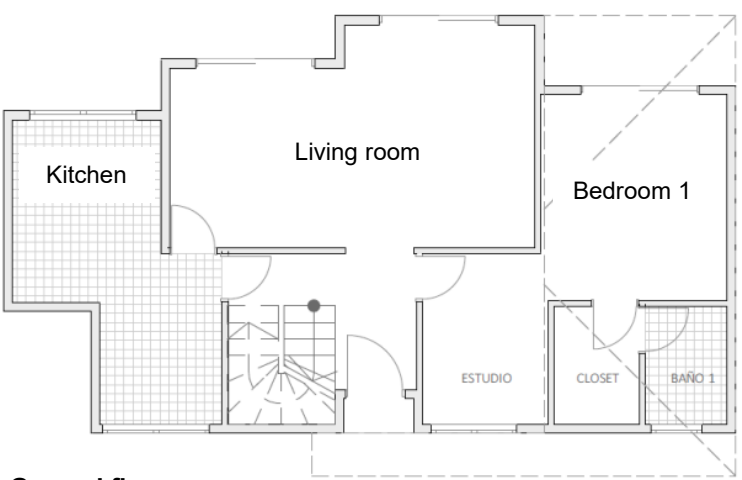

Ground floor
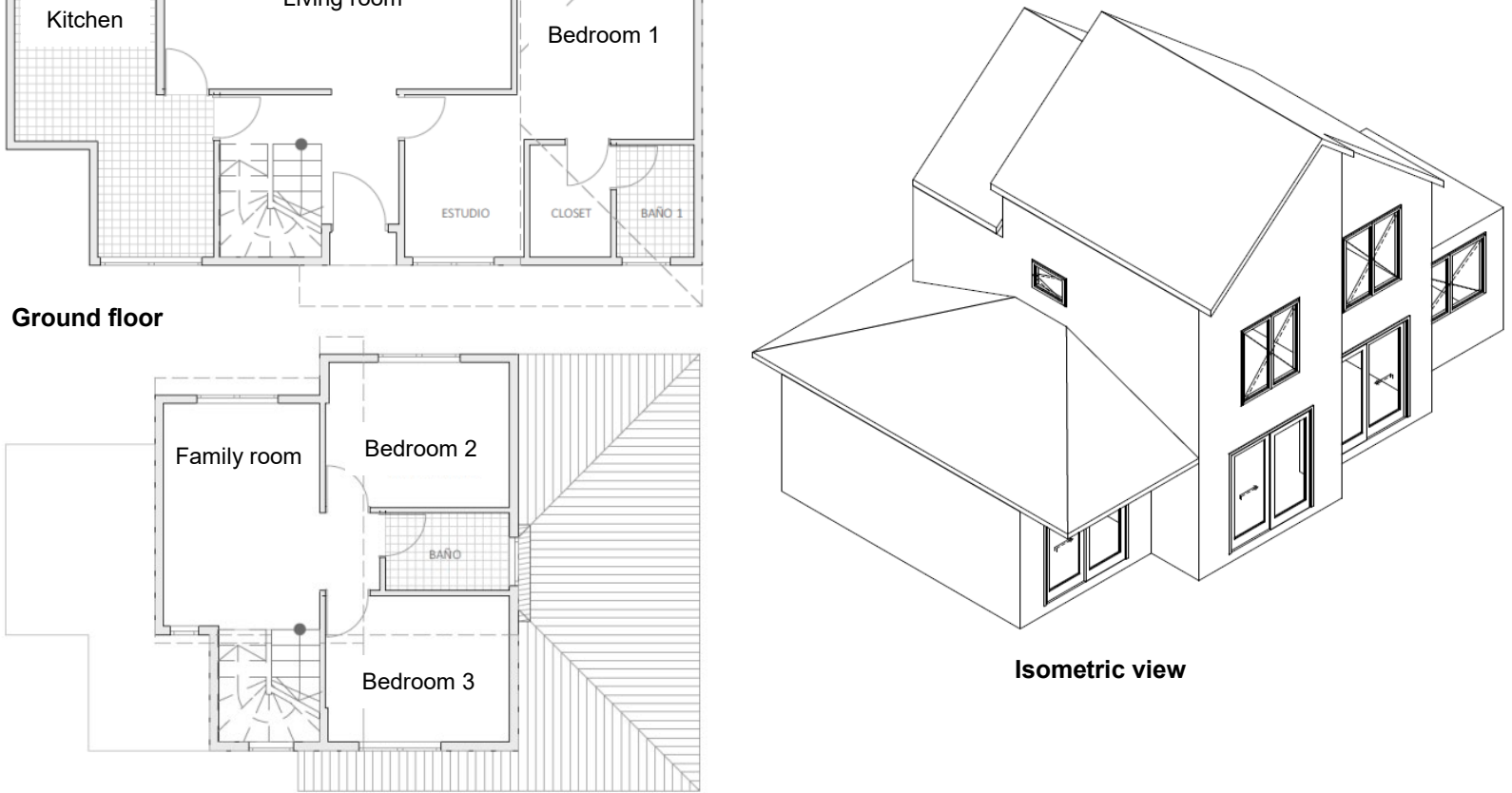

Isometric view

First floor

$\prod_{1} \prod_{2 \mathrm{~m}}$

(Note: 2-column fitting image)

Figure 3. Floor plans and isometric view of the representative house for type 2 

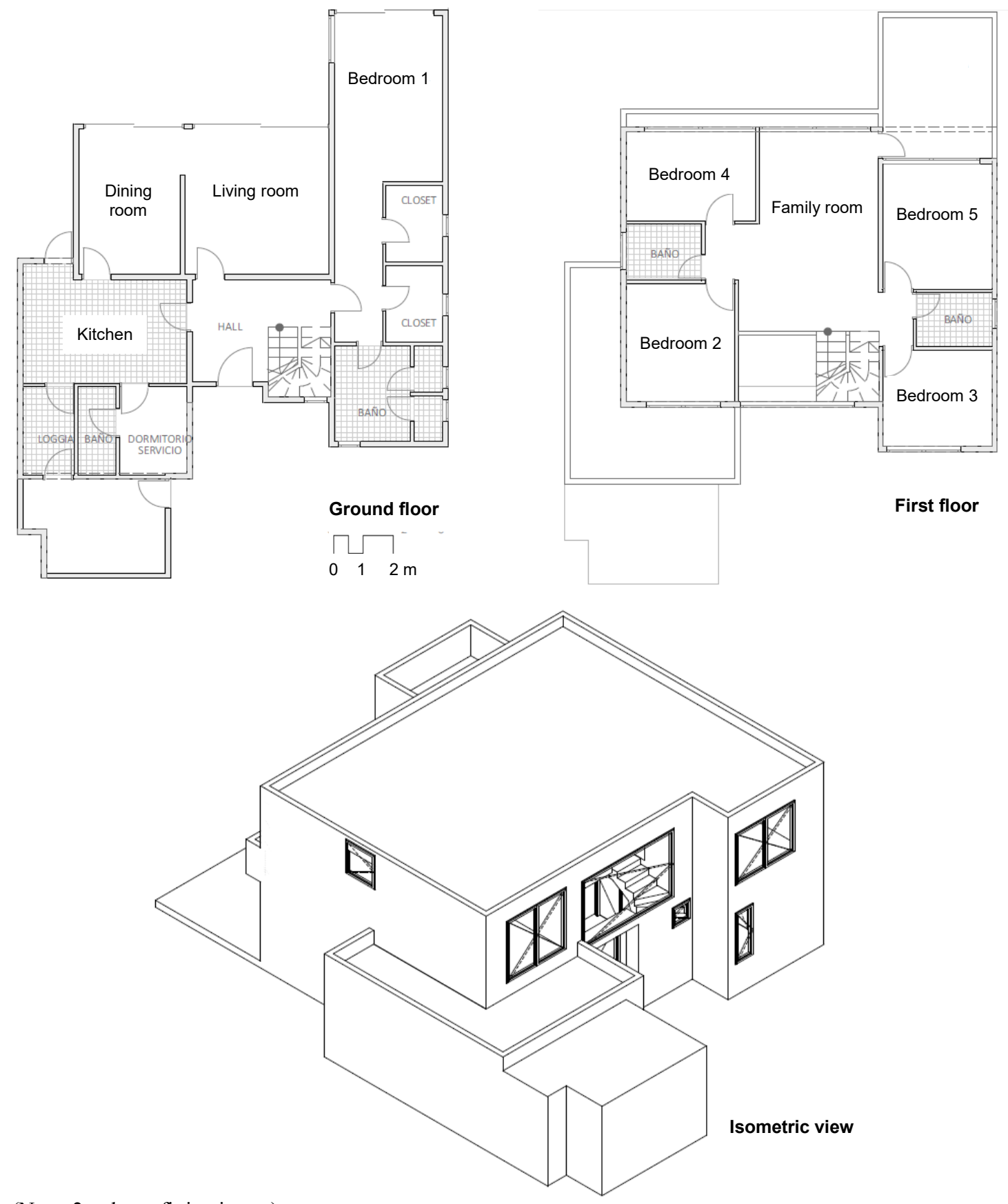

(Note: 2-column fitting image)

Figure 4. Floor plans and isometric view of the representative house for type 3

\subsection{Defining a cost-optimal analysis of the thermal envelope using the life cycle cost (LCC) method}

With the aim of considering all the investments and future operating costs that can affect the energyefficiency improvements from the point of view of both developers and consumers, we proposed a cost-optimal analysis of the thermal envelope based on the concept of life cycle cost (LCC). This approach was originally intended to guide designers in the estimation of the incremental costs of developing, producing, using or removing a particular item in a system (Asiedu and $\mathrm{Gu}, 1998$ ). More recently, LCC has been applied to the entire 
building design process. The technique was developed under the name of life cycle cost analysis. It provides an important opportunity for the development of sustainable construction because it is based on a long-term vision as opposed to the traditional perspective that seeks an immediate return on a minimum initial investment while ignoring future economic and environmental impacts (García-Erviti et al., 2015). The technique facilitates analysis by comparing costs over a specific period of time. It also takes into account relevant economic factors in terms of initial investment and future operating and replacement costs.

In recent years, LCC analysis has received a new impetus from the European Union thanks to Directive 2010/31/EU on the energy performance of buildings (Official Journal of the European Union, 2010). According to this regulation, the requirements for energy performance and construction elements should be defined to achieve an optimum cost balance between investment and energy saved through the life cycle of the building while selecting the most economically advantageous tender. Thus, despite the differences among member countries, minimum requirements can be defined according to the most stringent criteria of optimal cost levels. This Directive was supplemented by a delegated regulation, which establishes a comparative methodological framework for calculating optimal levels of profitability of the minimum energy efficiency requirements for buildings and construction elements (Official Journal of the European Union, 2012). In this context, the LCC calculation can be performed for a system or a component by considering the initial investment $\mathrm{Ci}$ (for each component of the system $\mathrm{j}$ ), the annual costs (based on the initial year $\tau 0$ ) and the final value. Subsequently, LCC is linked to the duration of calculation period $\tau$ according to the following equation (UNE-EN15459, 2008):

$$
L C C_{\tau}=C_{i}+\sum_{j}\left[\sum_{i=1}^{\tau}\left(C_{a, i}(j) \cdot R_{d}(i)\right)-V_{f, \tau}(j)\right]
$$

where:

LCC $\tau$ life cycle cost (with respect to starting year $\tau 0$ ) for the calculation period

$\mathrm{Ci} \quad$ initial investment cost

$\mathrm{Ca}, \mathrm{i}(\mathrm{j}) \quad$ annual cost, year $\mathrm{i}$, of component $\mathrm{j}$ (including operating costs and/or replacement)

$\mathrm{Vf}, \tau(\mathrm{j}) \quad$ final value of component $\mathrm{j}$ at the end of the calculation period (with respect to starting year $\tau 0$ )

Rd (i) discount rate for year i

For the purposes of this study, a calculation period of 20 years and a private discount rate of $12 \%$ were used.

This type of analysis requires the application of a complex method that typically includes a simulation model of energy performance and an optimisation method. This article presents a method based on a simplified tool for calculating energy performance and other factors to obtain a more robust estimate of LCC with low computational processing time. Our model is initially expressed on an annual basis and then integrated as a 
seasonal result ${ }^{6}$. The ISO 13790 standard was selected as an initial reference for the definition of the calculation algorithm used in the simplified version. This standard results in a calculation model based on a quasi-steady state model for annual energy demand for space heating in residential and non-residential buildings (ISO 13790, 2008) according to the following equation:

$$
Q_{H, n d}=\left(Q_{H, t r}+Q_{H, v e}\right)-\eta_{H, g n}\left(Q_{H, g n}\right)
$$

where:

$Q_{H, n d} \quad$ heating needs

$Q_{H, t r} \quad$ transmission heat losses

$Q_{H, v e} \quad$ ventilation heat losses

$Q_{H, g n} \quad$ heat gains through internal and solar sources

$\eta_{H, \mathrm{gn}} \quad$ dimensionless factor used for heat gains

In the previous expression, the transmission and ventilation heat losses are evaluated in terms of the so-called winter degree-days defined as the cumulative sum of the difference between the interior set-point temperature of the building and the outside temperature. The transmission heat losses also depend on the insulation level of the building, while the heat losses due to ventilation depend on its degree of ventilation and permeability. On the other hand, the heat input to the building is represented by the term of heat gains through internal and solar sources, and is diminished by the utilization factor. Thus, the solar gains depend on the solar radiation that enters through each window of the building, and therefore, depends on the area of windows, possible obstacles or solar protections, and their orientations. The internal heat sources of a building are typically the occupants themselves, the interior lighting and equipment. Finally, not all the heat that enters the building results in a reduction of the heating needs, but a part is lost again to the outside or causes overheating. The fraction of heat gains that are useful for reducing heating needs is given by the dimensionless factor used for heat gains.

The main difference of the proposed model with respect to the ISO 13790 standard is the incorporation of three coefficients, or correction factors, for the terms of the equation as follows:

$$
Q_{H, n d}=\left(C F_{H, t r} \cdot Q_{H, t r}+C F_{H, v e} \cdot Q_{H, v e}\right)-\eta_{H, g n}\left(C F_{H, g n} \cdot Q_{H, g n}\right)
$$

The introduction of these correction factors aims to adjust the results of the simplified model to those obtained using a detailed calculation tool. This procedure implies that the base case (and a number of additional

\footnotetext{
6 The months of May, June, July, August and September were considered the seasonal period for heating.
} 
iterations) must be defined and solved using thermal analysis simulation software (Environmental Design Solutions Limited, 2016) under dynamic conditions to obtain monthly results for heating demand. Then, the correction factors were obtained using a generalised reduced gradient (GRG) nonlinear Solver to search for the best approximation of the detailed results using the simplified model. The mean square errors obtained for the solution of the models adjusted by this procedure were $0.1 \%, 2.1 \%$ and $1.2 \%$ for Types 1,3 and 7 , respectively.

Finally, a sensitivity and uncertainty analysis was applied to all proposed typologies based on this calculation procedure. Model uncertainty was propagated in the adjusted model for estimating energy demand based on four input parameters associated with the thermal envelope in addition to the orientation, which were uniformly distributed. Then, the thermal transmittance of walls was defined for eight variations (i.e., 1.87, 0.98, 0.57, 0.41, $0.31,0.26,0.22$ and $0.19 \mathrm{~W} / \mathrm{m}^{2} \mathrm{~K}$ ), which ranged from no thermal insulation to a level close to a passive building (with $200 \mathrm{~mm}$ thermal insulation). Similarly, the thermal transmittance of roofs was defined for six variations from the minimum level required by current thermal regulations (i.e., $0.47,0.38,0.32,0.28,0.23$ and 0.20 $\mathrm{W} / \mathrm{m}^{2} \mathrm{~K}$ ), the thermal transmittance of soil (for conditions with and without thermal insulation along the perimeter) and the thermal transmittance of windows (for three types of glazing: single, double and double with low emissivity (low-E)). Based on the combination of these input parameters and their corresponding distributions, a sample matrix of 10,000 cases was defined using a Monte Carlo model for each type. Finally, to apply the adjusted model to calculate energy performance, 10,000 results for annual energy demand for heating per unit area $\left(\mathrm{kWh} / \mathrm{m}^{2}\right)$, investment costs and life-cycle costs were obtained for examples that ranged from housing built to meet only the minimum regulatory requirements (for the base case) to a combination of all service improvements per parameter (for the best case). This performance matrix constitutes the basis on which an efficient standard was established for optimising the thermal envelope.

\subsection{Evaluation of WTP for residential energy efficiency using a contingent valuation approach}

Due the practical absence of certified homes in the private real estate market in Chile where to observe consumers' preference in this paper we use Contingent Valuation (CV). Such approach, allows to assess, thorough an ad-hoc survey, willingness to pay (WTP) for more energy-efficient housing, that is, to incorporate improvements in the thermal envelope (i.e., walls, windows and ceilings) beyond the required minimum standard. $\mathrm{CV}$ is based on the idea that changes in individual utility can be expressed in terms of compensation and therefore can be expressed in monetary units (Mitchell and Carson, 1989; Riera, 1994). Due to the contingent nature of $\mathrm{CV}$ there are no warranties that in real situations respondents will pay the monetary amount 
they have declared. This issue is known as "hypothetical bias" (HB) and it is common to stated preference techniques (Marmolejo-Duarte and Bravi, 2017). HB is the divergence between actual and hypothetical statements of value. Ehmke et al. (2008) signal a number of reasons for the existence of such a bias: strategic response, uncertainty about one's value for the assessed good, commitment cost or social desirability bias. Such authors have found that the bias is not uniform across cultures but tends to be sharper in the U.S. but smaller in countries such as Niger, France and China; so the bias seems to be larger in well-developed economies. List and Gallet (2001) have found the HB is between 3.5 (stated/actual value) reaching, in very rare cases, a value of 10 . This results are in line with the National Oceanic and Atmospheric Administration's (NOAA) Blue Ribbon Panel recommendation, which suggested that hypothetical bids be deflected using a "divide by 2" approach when using CV. Finally, research inquiries have found that HB tends to be smaller when: [1] goods assessed are private, as opposed to public; [2] people are asked to state their willingness to pay (WTP) instead of their willingness to accept (WTA); [3] experiments are realistic (i.e. payment vehicles are familiar and people rely on the feasibility to provide the attributes of the assessed goods); and [4] individuals are carefully selected so as to ensure convenient experience and appropriate demographics (National Oceanic and Atmospheric Administration, 1996, 1994). Following the aforementioned recommendations in order to minimise the HB issue, in this paper we have: [1] assed energy efficiency in a private market; [2] using WTP instead of WTA (i.e. a price discount for losing the opportunity to improve the energy efficiency of homes); [3] used the purchasing price as vehicle of WTP extraction; and [4] surveyed a sample of actual potential buyers.

In the literature, CV has been extensively applied to determine preferences for green buildings (Chau et al., 2010; Kwak et al., 2010; Park et al., 2013; Zalejska-Jonsson, 2014) or renewable energy (Guo et al., 2014; Lee and Heo, 2016; Longo et al., 2008; Sundt and Rehdanz, 2015; Zhang and Wu, 2012; Zoric and Hrovatin, 2012). For the purposes of this research, we used open questions to extract WTP for the potential benefits obtained by improving the thermal envelope standards of homes, establishing an open-ended contingent valuation model (Giannakopoulou et al., 2017; Romano et al., 2016; Shi et al., 2014).

However, such questions often confuse respondents if no guidance is provided with respect to the response. Therefore, the participants were informed regarding the marginal costs and benefits in terms of energy savings (Table 3) associated with various combinations of energy-efficiency improvements and regarding the more effective costs obtained using the thermal envelope optimisation model. The combinations were maintained constant across the range of housing types although they resulted in different additional costs and savings depending on the surface areas of each representative housing type. It is worth saying that in most of the 
aforementioned $\mathrm{CV}$ studies the offered improvement (i.e. a betterment of energy efficiency) does not necessarily derives from an LCC analysis, in that this paper makes a steep forward. Although, our LCC estimations are that, potential savings that might differ from actual energy measurements due a number of reasons in which users' behaviour, among others, plays a paramount role. Indeed, according to the IEA EBC annex 53, building energy consumption is mainly influences by climate, building envelope, building services and energy systems, building operation and maintenance, occupant activities and behaviour, and indoor environmental quality, where the latter three - related to human behaviour - can have an influence as great as or even greater than the previous three (Hong et al., 2017; Santin, 2011; Yoshino et al., 2017). Due to this, it has been observed a "typical" $30 \%$ to $100 \%$ dicrepancies between predicted and actual energy use in buildings (Azar and Menassa, 2012), which even can reach up to $300 \%$ difference en certain cases (Delzendeh et al., 2017). For example, in Chile, it has been observed that variables such as daytime and night ventilation are one of the main sources of uncertainty related to the actual energy consumption, manily due to their dependence on the occupant behaviour (by means of windows opening) (Encinas and De Herde, 2011). For the sake of simplicity, in order to introduce such uncertainty in the CV survey, respondents were informed using a conditional tense on the possible energy savings, which were presented only as a "reference". Though respondents' confidence on provided saving estimations was not addressed in the survey, so there is a possibility that stated WTP might result influenced by such confidence.

At the same time, participants were clearly informed that they could be unwilling to pay. In such cases, we inquired regarding the reasons for that decision, in order to identify true zeros (i.e. null changes in perceived utility coming from the offered energy improvements) from strategic zeros (i.e. WTP not revelled). 
Table 3

Willingness to pay for improvements to the thermal envelope for Type 1 presented as asked in the survey

"Considering that the house you are looking to buy has the minimum building systems required by national regulations for thermal matters (i.e., single-glazing windows and brick walls without thermal insulation):

Would you be willing (a) to pay an amount of money additional to the cost of your home to have energy-efficiency improvements?

To make your decision, you can use the values provided in the table below as a reference, where, for example, replacing the single glazing of the windows with double glazing and adding $8 \mathrm{~cm}$ thermal insulation in the walls would add 1,900 $€$ to the price of your house but would save $270 €$ per year in heating costs."

\begin{tabular}{|c|c|c|c|}
\hline Window type & Thermal insulation in walls & Additional price to pay & Annual savings in heating \\
\hline Double glazing & Without thermal insulation & $500 €$ & $80 €$ \\
\hline Double glazing & $2 \mathrm{~cm}$ thermal insulation & $1,300 €$ & $190 €$ \\
\hline Double glazing & $8 \mathrm{~cm}$ thermal insulation & $1,900 €$ & $270 €$ \\
\hline Low-E* double glazing & $11 \mathrm{~cm}$ thermal insulation & $2,600 €$ & $320 €$ \\
\hline Low-E* double glazing & $20 \mathrm{~cm}$ thermal insulation & $3,900 €$ & $360 €$ \\
\hline
\end{tabular}

Note $(*)$ : Because low-E (low emissivity) double glazing represents a technical concept, it was presented in the survey as "high-efficiency double glazing."

The survey consisted of 11 questions, including the socio-demographic aspects of the participants, with the aim of characterising them. The survey was implemented in an online questionnaire and emailed to registered users of the Portalinmobiliario.com database who had been seeking new houses to buy in Santiago in recent months. Thus, the sample corresponded to an ideal target audience in which to investigate WTP, given that the research was aimed at new homes, not existing ones. With 373 completed surveys, the sampling frame was configured with a $5 \%$ margin of error for a confidence level of $95 \%$, which is considered satisfactory for the objectives and scope of this study. It is worth saying that despite the efforts to get more respondents the final figure remains significant, but low enough to allow more sophisticated WTP elicitations.

\section{Results}

One of the main objectives of LCC analysis is to determine the case for the minimum LCC value, which can be identified as the optimal case. However, there are many other cases of interest in the vicinity of the so-called efficiency frontier. For clarity, LCC is expressed in terms of LCC savings (relative to the base case), where the highest point of the point cloud that corresponds to 10,000 combinations of energy-efficiency improvements represents the optimum. In addition, all cases located on the efficiency frontier (also termed the Pareto front) represent the best combinations (i.e., the greatest LCC savings) with respect to energy demand for heating. Beyond the efficiency frontier are cases that should be discarded, that is, where for the same heating demand 
there are other cases with better LCC savings. Subsequently, the points of interest of the efficiency frontier were selected for Types 1, 2 and 3 (Figures 5, 6 and 7, respectively) as follows:

1) Base case (increased heating demand because it meets the minimum requirements with current thermal regulations and faces south)

2) Base case facing north (more favourable orientation)

3) First improvement in the window type (replacing single with double glazing)

4) Optimal case (greater LCC savings)

5) Second improvement in the window type (double glazing replaced by low-E double glazing)

6) Best case (lower demand for heating)

These six cases were also considered as references in defining the energy-efficiency improvements that would be considered in estimating WTP using the contingent valuation method. For this particular situation, it was of interest overall to assess the response of the participants regarding the most basic improvement (i.e., the replacement of single by double glazing; Point 3), the optimal case (Point 4) and the best case (Point 6). 


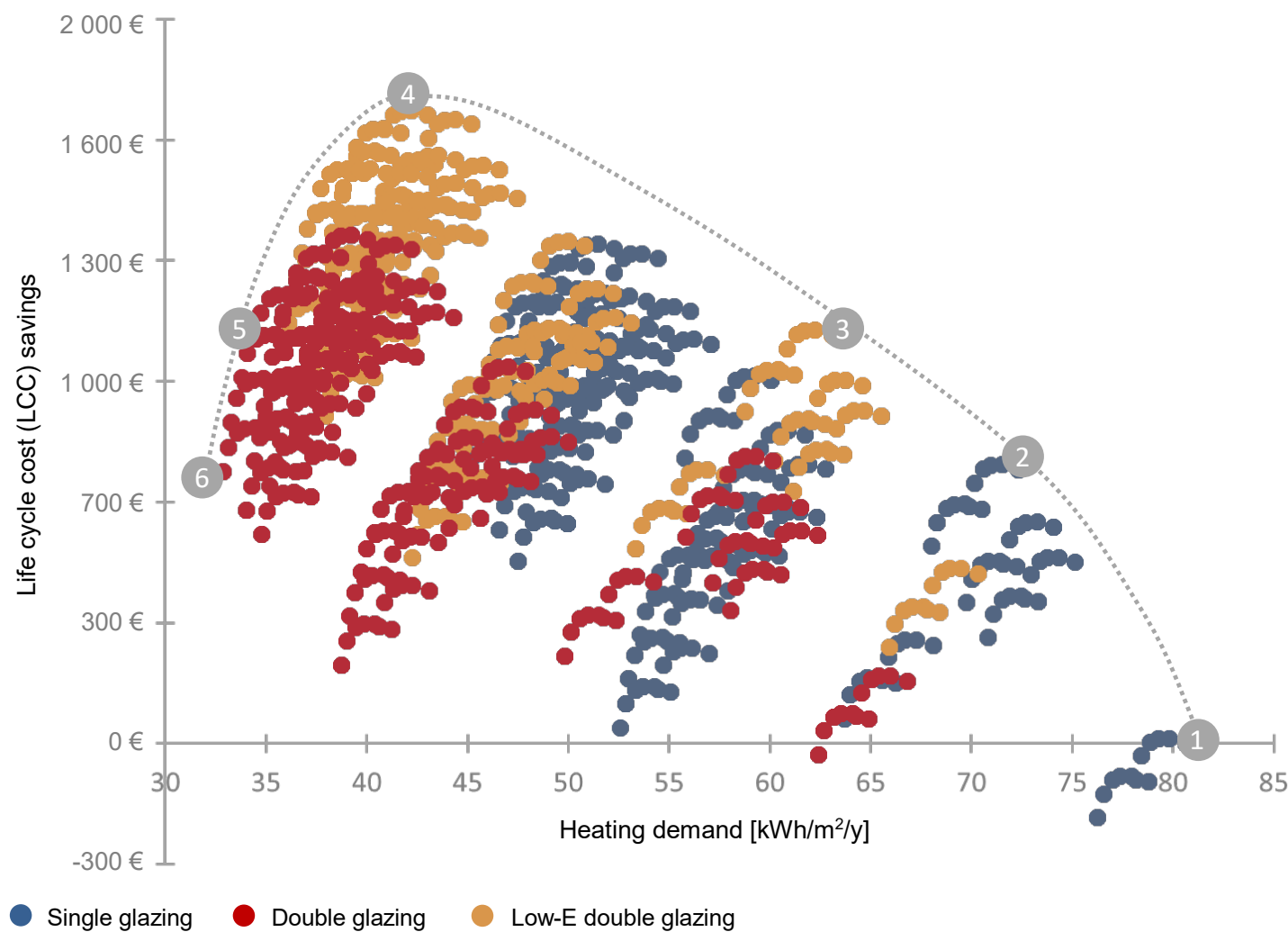

Figure 5. Definition of the efficient frontier from the cost-optimal analysis for type 1 by kind of window

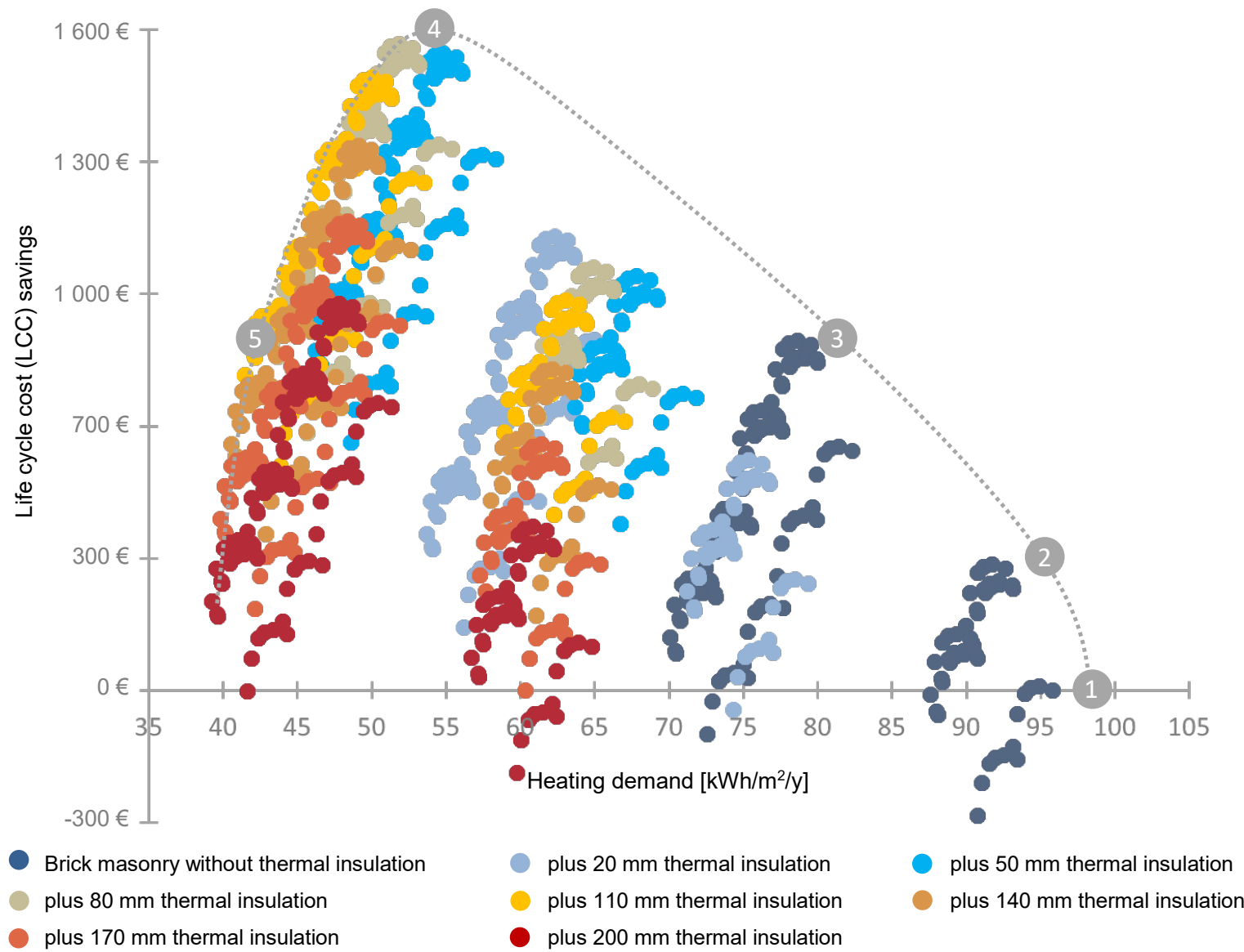

Figure 6. Definition of the efficient frontier from the cost-optimal analysis for type 2 by kind of wall 


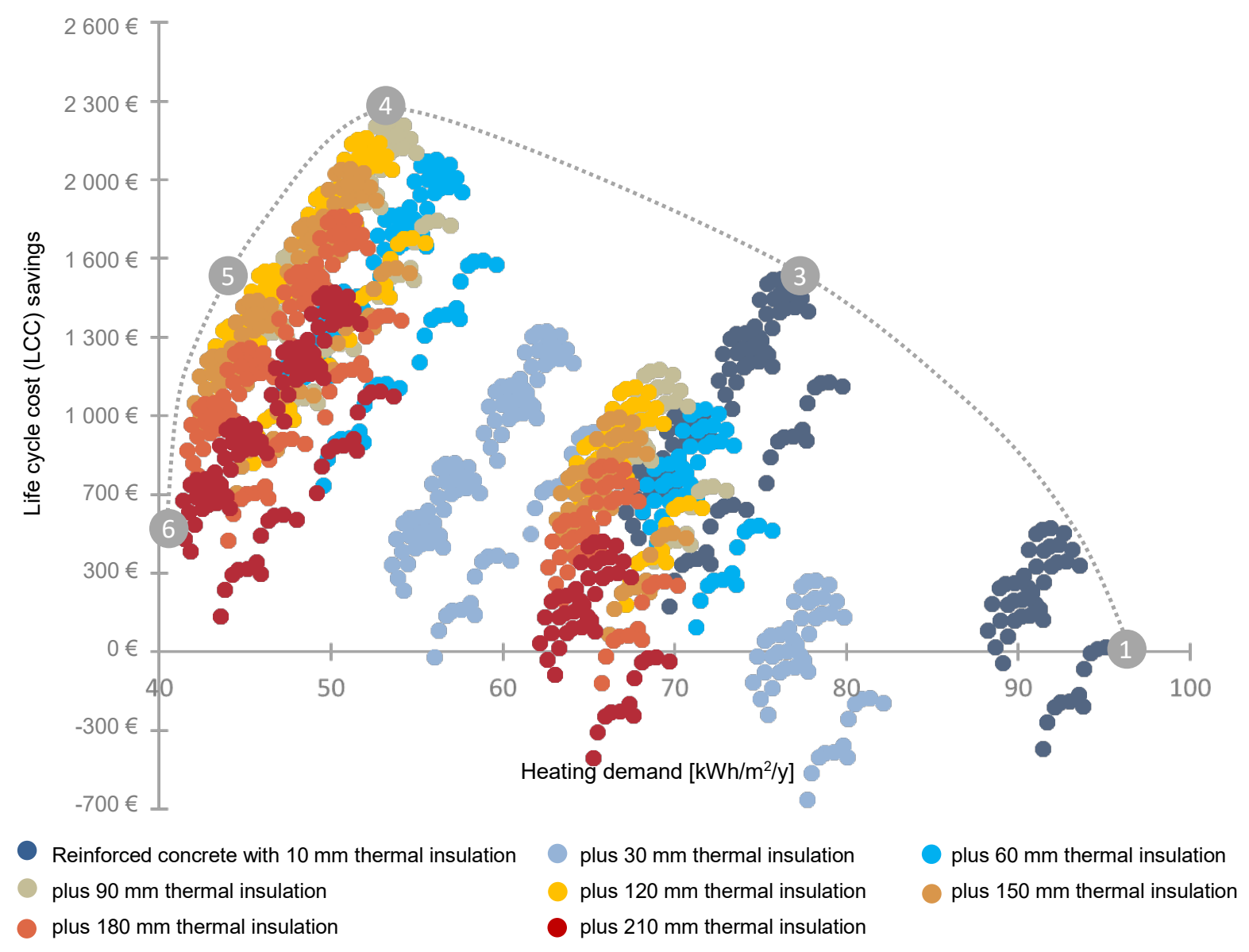

Figure 7. Definition of the efficient frontier from the cost-optimal analysis for type 3 by kind of wall

According to the results, the optimal case is achieved with the incorporation of double-glazed windows, between 80 and $90 \mathrm{~mm}$ thermal insulation in the walls (depending on whether construction solutions are based on masonry brick or reinforced concrete, respectively) and $100 \mathrm{~mm}$ thermal insulation in the roof for the three studied architectural typologies. The characterisation of the six points selected from the efficiency frontier is also presented for Types 1, 2 and 3 (Table 4 for Types 1 and 2; Table 5 for Type 3). It is important to consider that the building systems considered for the definition of the walls differed. They represent different construction qualities and therefore different construction costs, for example, the treatment for the reinforced concrete wall termed an exterior insulation finishing system (EIFS). 
Table 4

Characterisation of the points of interest selected for the cost-optimal analysis for Types 1 and 2

\begin{tabular}{cllll}
\hline Point of interest & Orientation & \multicolumn{1}{c}{ Window type } & \multicolumn{1}{c}{ Wall type* $^{*}$} & \multicolumn{1}{c}{ Roof type $^{* * *}$} \\
\hline 1 (base case) & South & Single glazing & $\begin{array}{l}\text { Brick masonry without } \\
\text { thermal insulation }\end{array}$ & $80 \mathrm{~mm}$ thermal insulation \\
2 & North & Single glazing & $\begin{array}{l}\text { Brick masonry without } \\
\text { thermal insulation }\end{array}$ & $80 \mathrm{~mm}$ thermal insulation \\
3 & North & Double glazing & $\begin{array}{l}\text { Brick masonry without } \\
\text { thermal insulation }\end{array}$ & $80 \mathrm{~mm}$ thermal insulation \\
4 (optimal case) & North & Double glazing & $\begin{array}{l}\text { Brick masonry with } 80 \mathrm{~mm} \\
\text { thermal insulation }\end{array}$ & $100 \mathrm{~mm}$ thermal insulation \\
5 & North & $\begin{array}{l}\text { Low-E double } \\
\text { glazing }\end{array}$ & $\begin{array}{l}\text { Brick masonry with } 110 \mathrm{~mm} \\
\text { thermal insulation }\end{array}$ & $170 \mathrm{~mm}$ thermal insulation \\
6 (best case) & North & $\begin{array}{l}\text { Low-E double } \\
\text { glazing }\end{array}$ & $\begin{array}{l}\text { Brick masonry with } 200 \mathrm{~mm} \\
\text { thermal insulation }\end{array}$ & $200 \mathrm{~mm}$ thermal insulation \\
\hline
\end{tabular}

Note (*): Considering expanded polystyrene of $15 \mathrm{~kg} / \mathrm{m}^{3}$ on the inside of the walls with a $10 \mathrm{~mm}$ plasterboard sheet as the interior finish.

(**): Considering mineral wool of $40 \mathrm{~kg} / \mathrm{m}^{3}$ with a $10 \mathrm{~mm}$ plasterboard sheet as the interior finish.

Table 5

Characterisation of points of interest selected for the cost-optimal analysis for Type 3

\begin{tabular}{|c|c|c|c|c|}
\hline Point of interest & Orientation & Window type & Wall type* & Roof type** \\
\hline 1 (base case) & South & Single glazing & $\begin{array}{l}\text { Reinforced concrete with } 10 \\
\mathrm{~mm} \text { thermal insulation }\end{array}$ & $80 \mathrm{~mm}$ thermal insulation \\
\hline 2 & North & Single glazing & $\begin{array}{l}\text { Reinforced concrete with } 10 \\
\mathrm{~mm} \text { thermal insulation }\end{array}$ & $80 \mathrm{~mm}$ thermal insulation \\
\hline 3 & North & Double glazing & $\begin{array}{l}\text { Reinforced concrete with } 10 \\
\text { mm thermal insulation }\end{array}$ & $80 \mathrm{~mm}$ thermal insulation \\
\hline 4 (optimal case) & North & Double glazing & $\begin{array}{l}\text { Reinforced concrete with } 90 \\
\text { mm thermal insulation }\end{array}$ & $100 \mathrm{~mm}$ thermal insulation \\
\hline 5 & North & $\begin{array}{l}\text { Low-E double } \\
\text { glazing }\end{array}$ & $\begin{array}{l}\text { Reinforced concrete with } 180 \\
\mathrm{~mm} \text { thermal insulation }\end{array}$ & $170 \mathrm{~mm}$ thermal insulation \\
\hline 6 (best case) & North & $\begin{array}{l}\text { Low-E double } \\
\text { glazing }\end{array}$ & $\begin{array}{l}\text { Reinforced concrete with } 110 \\
\text { mm thermal insulation }\end{array}$ & $200 \mathrm{~mm}$ thermal insulation \\
\hline
\end{tabular}

Note (*): Considering expanded polystyrene of $15 \mathrm{~kg} / \mathrm{m}^{3}$ on the outer side of the walls using an EIFS.

$(* *)$ : Considering mineral wool with $40 \mathrm{~kg} / \mathrm{m}^{3}$ with a $10 \mathrm{~mm}$ sheet of plasterboard as the interior finish.

From the results obtained by the survey used to assess WTP for improvements in energy efficiency, the sample can be characterised as $50 \%(\mathrm{~N}=187)$ for homes priced less than $98,000 €, 14 \%(\mathrm{~N}=54)$ for homes priced between 98,000 and $147,000 €$ and $12 \%(\mathrm{~N}=44)$ for homes costing more than $295,000 €$ (Figure 8). These percentages are consistent in relation to the real estate in Santiago defined as Types 1, 3 and 7. In addition, many respondents were concentrated in the age range between 30 and 45 years $(62 \%, \mathrm{~N}=229)$, were women $(56 \%$, $\mathrm{N}=208)$ and had university $(60 \%, \mathrm{~N}=223)$ or postgraduate education $(15 \%, \mathrm{~N}=55)$. However, in terms of household configuration, the data were more heterogeneous and divided mainly into couples without children 
$(31 \%, N=117)$, couples with children under 6 years $(42 \%, N=155)$ and couples with children between six and 18 years $(11 \%, \mathrm{~N}=70)$. These outcomes could be expected for a target sample of individuals seeking to buy houses (in contrast to apartments).

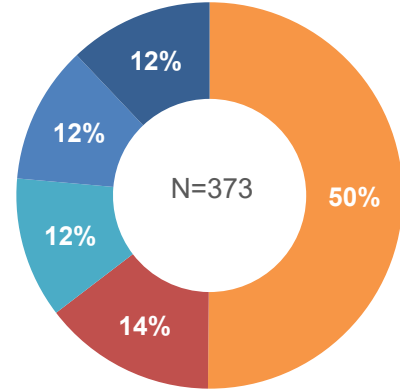

- Less than $98000 €$

- Between $98000 €$ and $147000 €$

Between $147000 €$ and $197000 €$

- Between $197000 €$ and $295000 €$

- More than $295000 €$

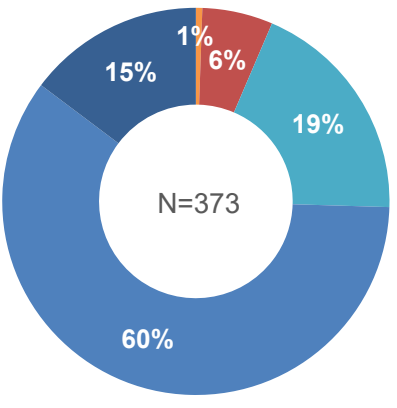

- Primary education

- Secondary education

- Technical education

- Universitary education

- Postgraduate education

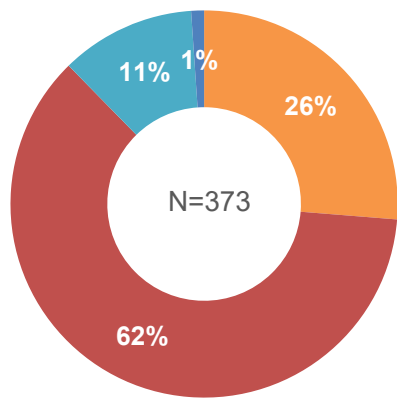

Between 18 and 30 years

- Between 30 and 45 years

- Between 45 and 65 years

- More than 65 years

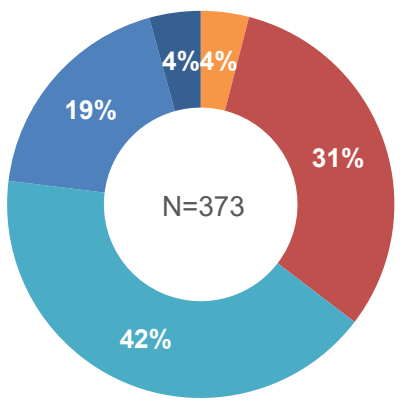

- Singles

- Couples without children

- Couples with children under 6 years

- Couples with children between 6 and 18 years

- Couples with children over 18 years

(Note: 2-column fitting image)

Figure 8. Segmentation of the sample obtained from the survey by price, age, gender, education and household configuration

Of a total of 373 valid surveys, most (84\%) stated that they were willing to pay, while only $16 \%$ of respondents said they were not willing to pay for proposed energy-efficiency improvements for a house they were considering buying. Of the 61 respondents who stated they were not willing to pay, most (53\%) indicated that they already pay too much for housing, $23 \%$ stated that the savings in heating seemed insufficient, and $11 \%$ did not consider residential energy efficiency important. As these results indicate, the main reason for an unwillingness to pay can be attributed to the relationship between final sale price and access to real-estate 
financing, which determines the maximum amount that can be paid for housing. Particularly in the lower price ranges, consumers eventually purchase "what they can afford" and therefore assume that these attributes should be incorporated into project costs. As noted by one respondent, "I think that asking about taking on an additional payment for energy savings scares consumers. Perhaps, such payment should be implicit in the value of the house as appropriate"(female, between 18 and 30 years old, college education).

WTP for improvements to the thermal envelope of houses, obtained from the survey, is presented for the three typologies selected via histograms and cumulative frequency (Figure 9) and linked to technical improvements proposed through the thermal envelope optimisation model (Tables 4 and 5). Because the typologies differ from one another in terms of area (useful and exposed envelope), the investment for each of the three presented upgrades - the replacement of single with double glazing, the optimal case and the best case (points 3,4 and 6, respectively) - also increases from the typologies associated with less expensive and smaller houses to the larger and more expensive houses. Thus, the maximum WTP varies from 3,900 € (Type 1 ) to 8,400 $€$ (Type 7). However, the percentage of individuals who were willing to pay for these improvements also increased relative to the price of the housing. In fact, for the improvement of replacing single with double glazing, WTP increased from $73 \%$ to $86 \%$ and $96 \%$ for Types 1,3 and 7 , respectively. For the optimal case that includes double glazing and 80 or $90 \mathrm{~mm}$ thermal insulation in walls - the difference increased by $40 \%$, $59 \%$ and $64 \%$ for the same types, respectively. For the best case, which corresponds to a high performance standard for climate requirements in Santiago, the percentage ranged from $7 \%$ for Types 1 and 3 to $11 \%$ for Type 7. These outcomes suggest a positive correlation between the price of housing and WTP for improvements in energy efficiency, hypothesis that is further tested using a statistical model. 

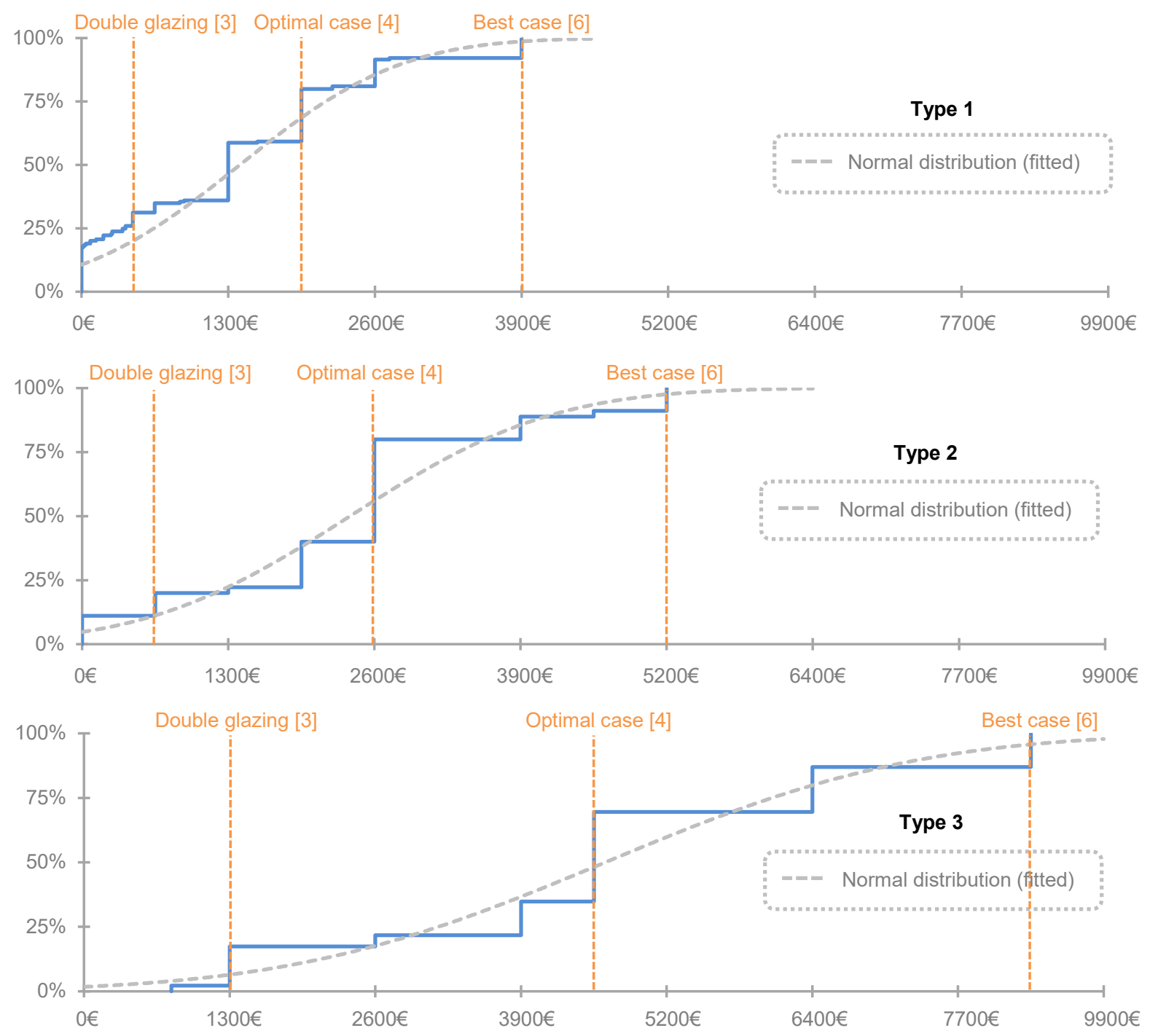

Note: points of interest from the thermal envelope optimisation models (Tables 4 and 5) are between square brackets

Figure 9. Cumulative frequency histograms of WTP for improvements in energy efficiency by house typologies

Finally, with aim of establishing a model that can explain WTP from the socio-demographic and variables gleaned in the survey, a linear regression was selected $\left(\mathrm{R}^{2}=0.6\right)$, which is represented by the following equation: $W T P=2,373,337 X_{1}+1,563,196 X_{2}+681,749 X_{3}+627,160 X_{4}+379,598 X_{5}+300,357 X_{6}+938,163$

where $\mathrm{X}_{\mathrm{i}}$ etc. are the independent variables that explain the model, and correspond to following:

$\mathrm{X}_{1}$ houses that the respondents are seeking to buy with an offer price higher than $295,000 €$

$\mathrm{X}_{2}$ houses that the respondents are seeking to buy with an offer price between 197,000 and $295,000 €$

$\mathrm{X}_{3}$ houses that the respondents are seeking to buy with an offer price between 147,000 and $197,000 €$

$\mathrm{X}_{4}$ houses that the respondents are seeking to buy with an offer price between 98,000 and $147,000 €$

$\mathrm{X}_{5}$ respondents with postgraduate education who stated they engage in environmentally friendly behaviours

$\mathrm{X}_{6} \quad$ couples with children under five years 
The results of the regression model suggest that WTP is positively influenced by income level (indirectly evaluated using the price range of the house that the respondents were seeking to buy), educational level and other demographic aspects. Regarding the latter, of the various possibilities that were tested, two combined variables were statistically significant: households with young children and respondents with higher education who claimed to engage in environmentally friendly behaviour ${ }^{7}$. These two profiles were to be expected according to anecdotic relates from local real-estate sales experience are consistent with the international literature and correlate with WTP for renewable energy (Adaman et al., 2011), reduced $\mathrm{CO}_{2}$ emissions (Chekima et al., 2015) and, more broadly, sustainable products (MINVU, 2014b).

\section{Discussion}

\subsection{Perspectives for real-estate developers}

The results of the cost-optimal analysis obtained using the LCC method reveal that nearly all combinations of energy-efficiency improvements are profitable with respect to the 20 -year evaluation horizon. The only combinations that are not profitable (which correspond to $0.12 \% ; 0.24 \%$ and $0.45 \%$ of total cases for Types 1,3 and 7 , respectively) concern combinations such as 1) single glazing, walls without thermal insulation and thick insulation in roofs or 2) sealed double-glazed low-E glass windows with walls without thermal insulation. While these combinations appear illogical from the perspective of the overall energy performance of housing, they clearly warn of the risk of conceiving of the sustainability strategy of the project solely based on the logic of isolated attributes ${ }^{8}$.

It could also be observed that for all identified typologies, there was a WTP of between $40 \%$ and $60 \%$ (with the highest percentages associated with more expensive homes) for the cost-optimal solution obtained from all possible combinations. This optimal case, defined according to the LCC model, is achieved in all home typologies by incorporating double-glazed windows, between 80 and $90 \mathrm{~mm}$ thermal insulation in walls (depending on whether the construction is based on masonry brick or reinforced concrete, respectively) and 100

\footnotetext{
7 In the survey, the respondents could indicate their engagement in the following environmentally friendly behaviours (more than one answer was possible): (1) I apply energy-efficiency measures in my home (e.g., lighting, gas); (2) I recycle at home; (3) I belong to an environmental group; (4) I donate to an environmental organisation; (5) I use public transportation instead of private; (5) I use a bicycle as a means of transportation.

8 Thus, in investigating the attributes of energy efficiency in the housing supply, several such cases were observed, e.g., houses with doubleglazed low-E windows and walls that met only the minimum thermal regulation. Although such combinations may sound absurd, they are not so from the perspective of real-estate marketing, particularly when a highly striking attribute, such as double-glazed low-E windows, is being promoted.
} 
$\mathrm{mm}$ thermal insulation in roofs. However, survey participants exhibited WTP not only for the optimal case or less expensive solutions but also for the best case (at a percentage on the order of $7 \%$ to $11 \%$ ), which includes low-E double glazing and $200 \mathrm{~mm}$ thermal insulation in walls and roof. This outcome suggests a potential demand for homes with high energy-performance standards in the Santiago real-estate supply. While this demand would be associated with certain niche markets for higher-priced homes, it is interesting because it indicates a need for a real-estate product that - at least in mass production - is currently lacking.

\subsection{Public-policies implications}

In relation to the thermal envelope optimisation model, it can be observed how defining the optimal case coincides with the social optimum identified for Santiago in a study performed for updating national thermal regulations (DITEC, 2013a), in which the most serious health impacts were incorporated into the evaluation ${ }^{9}$. This coincidence concerning the $80 \mathrm{~mm}$ thermal insulation in walls (when the construction is based on brick masonry) is particularly interesting not only because the optimal case and the social optimum are based on different inputs (i.e. discount rates of $12 \%$ and $6 \%$, respectively) but also because one exclusively evaluates energy efficiency, while the impacts of particulate matter from the heating system were added to the other.

In a study performed in the context of developing the certification instrument, it was estimated that letters $\mathrm{C}$ and $\mathrm{D}$ correspond to the optimal scenario from the perspective of private profitability, while letters A and B correspond to a scenario of high investment cost. This reasoning appeared in a presentation used to promote the energy rating to the construction sector (DITEC, 2013b). However, having barely progressed in the implementation of the energy rating, the message from the Ministry of Housing and Urban Development changed after it was established that letters $\mathrm{C}$ and D corresponded to the "optimal scenario for public housing projects," while A and B corresponded to "the optimal setting for private projects" (DITEC, 2015). This change in the definition of the optimal scenario was not based on technical considerations (given that the reference standards and calculation models contained in the energy rating remained the same) but on a communication tactic that was developed when the strategies associated with the energy rating's intermediate levels were

\footnotetext{
9 When only the lowest level of health impact is considered (or not even considered), the social optimum would be determined by 50 mm thermal insulation in walls, which still coincides with the thermal envelope optimisation model described in this study. In fact, Figure 9 shows how at the efficiency frontier, $50 \mathrm{~mm}$ wall insulation (for brick-based construction) is close to the $80 \mathrm{~mm}$ defined as the optimal case. In this sense, what clearly diverge from the optimum are the cases with no thermal insulation in walls.
} 
declared to not be the most cost-effective, which was not well received by the industry ${ }^{10}$. The current version of this presentation avoids discussing the optimal level and merely states that letters $\mathrm{C}$ and $\mathrm{D}$ are associated with "efficient housing without excessive investment cost" (Ministerio de Vivienda y Urbanismo, 2016).

These circumstances underscore the importance of how energy efficiency and sustainability are communicated in the context of the housing market. In this line, Encinas et al. (2018), for the Santiago de Chile housing market, shows how real estate developers instead of use the official certification scheme for energy efficiency, do include in the advertisement of their promotions isolated attributes of sustainability as a marketing strategy. Nonetheless, such information is incomplete and does not fill the gap of information provision discussed by Allcott and Taubinsky (2015), since such marketing approach: 1) does not help consumers to correctly estimate the cost savings, 2) does not help consumers to assess the energy benefits of different homes, 3) and does not provide cognitive resources to help them to correctly represent the true value of energy efficiency. It is important to note that buyers are, in general, unaware of the economic and environmental benefits of energy efficiency attributes since most of them derivate from new technologies (i.e. efficient boilers) or new normative requirements (i.e. wall insulation). So the chances that they learn from the past experience are close to zero. International experience, particularly regarding EPCs, suggests that such tools can encourage the market to move towards the provision of real-estate products with higher levels of energy efficiency, for example, by market premiums associated with the best-qualified housing

As noted, the contingent valuation model results suggested the possibility of introducing real-estate products with significantly higher energy-performance standards if WTP for these standards could be demonstrated. The introduction of such products would encourage competitiveness in the market while generating the best realestate products in terms of quality and subsequent sales and supporting suppliers of energy-efficient construction solutions and technologies. In addition, the model results may represent a signal to improve the mandatory minimum standards established in the national thermal regulations. In this regard, a regulation that proposes a standard that does not require the use of thermal insulation should be unacceptable, particularly when the country has set a goal of limiting heating energy demand for the climate region of Santiago to $71,52,35$ and $15 \mathrm{kWh} / \mathrm{m}^{2}$ for the years 2020, 2030, 2040 and 2050, respectively (MINVU, 2016b) ${ }^{11}$.

\footnotetext{
${ }^{10}$ In interviews, real-estate industry representatives stated that it was not attractive for them to promote homes that would receive a letter in the middle of the ratings range upon increasing their energy efficiency. Compounding matters was the comparison with energy labelling implemented beforehand (for example, with home appliances), where there is a perception that obtaining higher levels is not difficult.

${ }^{11}$ As a reference, a semi-detached public housing unit of $38 \mathrm{~m}^{2}$ facing north (i.e., in a favourable orientation) that minimally complies with the thermal regulations has an estimated heating demand of $100 \mathrm{kWh} / \mathrm{m}^{2}$ (Bustamante et al., 2009b)
} 
An interesting survey result, from the perspective of public policy, was the reasons why consumers would be unwilling to pay for energy-efficiency improvements in their new homes. In the sample, $11 \%$ of the respondents stated that they did not consider residential energy efficiency important. However, this result varies significantly when the data is segmented according to different housing price ranges. For example, in the lower range of less than $98,000 €$, this value reaches $15 \%$, while for the most expensive homes (i.e., more than $262,000 €$ ), this response does not occur. This finding reveals the differences about energy efficiency perception that may be influenced with education level associated to consumers' purchase capacity. That is, there are different levels of perception of and knowledge regarding sustainability in the various housing submarkets (DEFRA, 2007; Lippincott Mercer, 2006; Young et al., 2010; Zhou and Bukenya, 2016). The obtained WTP strongly correlated with income level. Thus, we identified a respondent profile with greater cultural capital and environmental sensitivity as the most likely to associate energy-efficient improvements with the purchase of a home. Public policy should be sensitive to these differences, particularly because there is a substantially closer relationship between sales price and real-estate financing as a determinant of the maximum amount paid for housing among individuals with lower income levels. As one respondent stated, "it is important to consider more information regarding the benefits that energy efficiency has in all its applications and the economic and environmental savings that this entails (...) for the awareness of the population and/or to generate cost savings in the long run" (female, between 30 and 45 years old, college education).

\section{Conclusions}

This article investigates willingness to pay for improvements in the energy efficiency of buyers for new homes based on a representative investment/operation cost analysis (using the life cycle cost method - LCC -) from the real-estate market of Santiago de Chile, which in turn is the most relevant in the country. This approach has been addressed. to open the debate on the convenience of modify the national construction code and rethink the energy certification scheme as well as an exploratory study to undercover further research lines to support the aforementioned debate.

In brief our analysis suggests that: [1] there is a number of potential home buyers ready to pay for energy efficiency when they are informed on the cost savings associated to structural modifications and the cost of providing such improvements (i.e LCC method) ; [2] such WTP and the unwillingness to pay is not monolithic across the respondents, but seems to be influenced by the education level plausibly associated to the purchase power (i.e. there is a correlation between purchase power and the rate of people unwilling to pay); [3] 
nonetheless, according to the study of Encinas et al. (2018), developers provide far from perfect information on the energy efficiency of homes, instead they use a marketing approach to include "sustainable attributes" on the advertisement with any suggest of its economic nor environmental implications (and consequently does not fill the gap of information provision discussed by Allcott and Taubinsky (2015)); and [4] the number of certified homes results risible in relation to the total completed. Such findings shed light on the necessity to furtherly identify the causes of the apparent mismatching between consumer's desires and developers' products in order to carefully design corrective measures if needed. Also, it contributes to identify whether powerfully informed transactions could help to incentive the consumption of energy efficient homes.

The limitations of the research can be understood by the fact that WTP is extracted using declared preferences since the really small quantity of certified homes prevents the use of observed preferences methods. In doing so there is a chance for a hypothetical bias (i.e. respondents might state a value for energy efficiency different from the one that they would pay in a real transaction). Nonetheless, we expect such bias, if it exists, to be small since: [1] respondents were recruited among people looking to buy a home; [2] energy efficiency is embedded as an attribute for a private market; [3] the payment vehicle is familiar to home buyers; [4] the design was formulated to declare the WTP. Also, our empirical design is not addressed to identify the causes of energy efficiency gap related to market failures as discussed by Gillingham and Palmer (2014) and Gillingham et al. (2009), nor to prove the effectiveness of adopting a mandatory certification scheme like the EPC in the European Union in order to foster the use of energy efficient homes by breaking energy efficiency opacities. Furthermore, Allcott and Taubinsky (2015) have proven that, in the market of lightbulbs, the improvement of information (i.e. reduction of informative asymmetries) do not necessarily leads to use energy efficient devices (i.e. CFL) instead of inefficient ones (i.e. incandescent); but subsides are needed.

\section{Acknowledgements}

This research received funding from the National Commission for Scientific and Technological Research of Chile CONICYT through the FONDECYT Research Initiation Project No.11130556 “Analysis and positioning of the attributes of energy efficiency and sustainability in the residential housing market of Santiago." We also received support from the Centre for Sustainable Urban Development (CEDEUS), CONICYT/FONDAP Project 15110020. The authors would like to acknowledge Portal Inmobiliario.com for providing the information about the real estate market in Santiago de Chile that made this research possible.

Conflicts of interest: none 


\section{References}

Adaman F, Karalidotless N, Kumbaroĝlu G, Or I, Özkaynak B, Zenginobuz Ü. What determines urban households' willingness to pay for CO2 emission reductions in Turkey: A contingent valuation survey. Energy Policy 2011;39:689-98. doi:10.1016/j.enpol.2010.10.042.

Allcott H, Taubinsky D. Evaluating behaviorally motivated policy: Experimental evidence from the lightbulb market. Am Econ Rev 2015;105:2501-38. doi:10.1257/aer.20131564.

Asiedu Y, Gu P. Product life cycle cost analysis: State of the art review. Int J Prod Res 1998;36.

de Ayala A, Galarraga I, Spadaro J V. The price of energy efficiency in the Spanish housing market. Energy Policy 2016;94:16-24. doi:10.1016/j.enpol.2016.03.032.

Azar E, Menassa CC. A comprehensive analysis of the impact of occupancy parameters in energy simulation of office buildings. Energy Build 2012;55:841-53. doi:10.1016/j.enbuild.2012.10.002.

Bio Intelligence Service, Lyons R, IEEP. Energy performance certificates in buildings and their impact on transaction prices and rents in selected EU countries 2013.

Bourassa SC, Hamelink F, Hoesli M, MacGregor BD. Defining Housing Submarkets. J Hous Econ 1999;8:16083. doi:10.1006/jhec.1999.0246.

Bruegge C, Carrión-Flores C, Pope JC. Does the housing market value energy efficient homes? Evidence from the energy star program. Reg Sci Urban Econ 2015. doi:10.1016/j.regsciurbeco.2015.12.001.

Bunster V, Noguchi M. Profiling Space Heating Behavior in Chilean Social Housing: Towards Personalization of Energy Efficiency Measures. Sustainability 2015;7:7973-96. doi:10.3390/su7067973.

Bustamante W. Informe $\mathrm{N}^{\circ} 6$. Evaluación económica social, artículo 4.1.10 de la Ordenanza General de Urbanismo y Construcciones. Ministerio. Santiago: 2013.

Bustamante W, Cepeda R, Martínez P, Santa María H. Eficiencia energética en vivienda social: un desafío posible. Camino al Bicenten. Propuestas para Chile, Santiago: Pontificia Universidad Católica de Chile, Vicerrectoría de Comunicaciones y Asuntos Públicos; 2009a, p. 253-82.

Bustamante W, Rozas Y, Cepeda R, Encinas F, Martínez P. Guía de Diseño para la Eficiencia Energética en la Vivienda Social. Santiago: Pontificia Universidad Católica de Chile; 2009b.

Caldera Sánchez A. Building Blocks for a Better Functioning Housing Market in Chile. Paris: OECD Publishing; 2012. doi:10.1787/5k9fj3hgsnvh-en.

CChC. Mercado Inmobiliario - Oferta Nacional y Gran Santiago. Indicadores 2017. http://www.cchc.cl/centrode-informacion/indicadores/mercado-inmobiliario-oferta-nacional (accessed October 9, 2017).

Celis F, García R, Trebilcock M, Escorcia O, Miotto U, Diaz M. Análisis energético de las viviendas del centrosur de Chile. Arquiteturarevista 2012;8:62-75. doi:10.4013/arq.2012.81.07.

Chau CK, Tse MS, Chung KY. A choice experiment to estimate the effect of green experience on preferences and willingness-to-pay for green building attributes. Build Environ 2010;45:2553-61. doi:10.1016/j.buildenv.2010.05.017.

Chekima B, Syed Khalid Wafa SAW, Igau OA, Chekima S, Sondoh SL. Examining green consumerism motivational drivers: does premium price and demographics matter to green purchasing? J Clean Prod 2015;112:3436-50. doi:10.1016/j.jclepro.2015.09.102.

Collados E, Armijo G. Predicting the impacts of an energy refurbishing programme in Chile: More than energy 
savings. In: Mumovic D, Santamouris M, editors. A Handb. Sustain. Build. Des. Eng. An Integr. approach to energy, Heal. Oper. Perform. Build. First edit, Earthscan Ltd.; 2008.

DEFRA. A framework for pro-environmental behaviours. London: 2007.

Delzendeh E, Wu S, Lee A, Zhou Y. The impact of occupants' behaviours on building energy analysis: A research review. Renew Sustain Energy Rev 2017;80:1061-71. doi:10.1016/j.rser.2017.05.264.

Dinan TM, Miranowsky JA. Estimating the implicit price of energy efficiency improvements in the residential housing market: A hedonic approach. J Build Econ 1989;25:52-67.

DITEC. Sistema de calificación energética de viviendas en Chile. Santiago: División Técnica de Estudio y Fomento Habitacional, Ministerio de Vivienda y Urbanismo; 2015.

DITEC. Construcción Sustentable. Santiago: División Técnica de Estudio y Fomento Habitacional, Ministerio de Vivienda y Urbanismo; 2013a.

DITEC. Calificación energética de viviendas. Santiago: División Técnica de Estudio y Fomento Habitacional, Ministerio de Vivienda y Urbanismo; 2013b.

Ehmke MD, Lusk JL, List J a. Is Hypothetical Bias a Universal Phenomenon? A Multinational Investigation. Land Econ 2008;84:489-500. doi:10.3368/le.84.3.489.

Encinas F. Probabilistic Analysis of Passive Cooling Strategies and Occupant Behaviour for improving the summer comfort conditions in apartments of the Santiago real estate market. Louvain-La-Neuve: Presses universitaires de Louvain; 2012.

Encinas F, Aguirre C. Sustentabilidad y mercado: aproximaciones desde la promoción inmobiliaria. ACE Archit City Environ 2017;12:137-64. doi:10.5821/ace.12.35.5141.

Encinas F, Aguirre C, Marmolejo-Duarte C. Sustainability Attributes in Real Estate Development: Private Perspectives on Advancing Energy Regulation in a Liberalized Market. Sustainability 2018;10:146. doi:10.3390/su10010146.

Encinas F, De Herde A. Sensitivity analysis in building performance simulation for summer comfort assessment of apartments from the real estate market. Energy Build 2013;65:55-65. doi:10.1016/j.enbuild.2013.05.047.

Encinas F, De Herde A. Definition of occupant behaviour patterns with respect to ventilation for apartments from the real estate market in Santiago de Chile. Sustain Cities Soc 2011;1:38-44. doi:10.1016/j.scs.2010.08.005.

Encinas F, Marmolejo C, Aguirre C. El impacto de los proyectos inmobiliarios y sus atributos de sustentabilidad sobre el valor del suelo: ¿causa o consecuencia? Dos estudios de casos para Santiago de Chile. Rev Hábitat Sustentable 2016;6:70-9.

Environmental Design Solutions Limited. EDSL TAS 2016. http://www.edsl.net/main/.

Fuerst F, McAllister P, Nanda A, Wyatt P. Energy performance ratings and house prices in Wales: An empirical study. Energy Policy 2016;92:20-33. doi:10.1016/j.enpol.2016.01.024.

Fuerst F, McAllister P, Nanda A, Wyatt P. Does energy efficiency matter to home-buyers? An investigation of EPC ratings and transaction prices in England. Energy Econ 2015;48:145-56. doi:10.1016/j.eneco.2014.12.012.

Fuerst F, McAllister P, Nanda A, Wyatt P. Final Project Report: An investigation of the effect of EPC ratings on house prices. London: Department of Energy \& Climate Change; $2013 \mathrm{a}$.

Fuerst F, McAllister PM, Nanda A, Wyatt P. Is Energy Efficiency Priced in the Housing Market? Some Evidence from the United Kingdom. SSRN Electron J 2013b:1-34. doi:10.2139/ssrn.2225270.

Fuerst F, Shimizu C. Green Luxury Gods? The Economics of Eco-Labels in the Japanese Housing Market. J Jpn 
Int Econ 2016. doi:10.2139/ssrn.2430879.

García-Erviti F, Armengot-Paradinas J, Ramírez-Pacheco G. El anális del coste del ciclo de vida como herramienta para la evaluación económica de la edificación sostenible. Estado de la cuestión. Inf La Construcción 2015;67:e056. doi:10.3989/ic.12.119.

Gelegenis J, Diakoulaki D, Lampropoulou H, Giannakidis G, Samarakou M, Plytas N. Perspectives of energy efficient technologies penetration in the Greek domestic sector, through the analysis of energy performance certificates. Energy Policy 2014;67:56-67. doi:10.1016/j.enpol.2013.09.051.

Giannakopoulou S, Xypolitakou E, Damigos D, Kaliampakos D. How visitors value traditional built environment? Evidence from a contingent valuation survey. J Cult Herit 2017;24:157-64. doi:10.1016/j.culher.2016.11.004.

Gillingham K, Newell RG, Palmer K. Energy Efficiency Economics and Policy. Annu Rev Resour Econ 2009;1:597-620. doi:10.1146/annurev.resource.102308.124234.

Gillingham K, Palmer K. Bridging the Energy Efficiency Gap: Policy Insights from Economic Theory and Empirical Evidence. Rev Environ Econ Policy 2014;8:18-38. doi:10.1093/reep/ret021.

Guo X, Liu H, Mao X, Jin J, Chen D, Cheng S. Willingness to pay for renewable electricity: A contingent valuation study in Beijing, China. Energy Policy 2014;68:340-7. doi:10.1016/j.enpol.2013.11.032.

Hong T, Yan D, D’Oca S, Chen C fei. Ten questions concerning occupant behavior in buildings: The big picture. Build Environ 2017;114:518-30. doi:10.1016/j.buildenv.2016.12.006.

Hyland M, Lyons RC, Lyons S. The value of domestic building energy efficiency - evidence from Ireland. Energy Econ 2013;40:943-52. doi:10.1016/j.eneco.2013.07.020.

ISO 13790. Energy performance of buildings - Calculation of energy use for space heating and cooling. Geneve: International Organization for Standardization; 2008.

Jansen S. Chapter 5. The Multi-attribute Utility Method. In: Jansen S, Coolen H, Goetgeluk R, editors. Meas. Anal. Hous. Prefer. Choice, 2011, p. 101-25. doi:10.1007/978-90-481-8894-9.

Kahn ME, Kok N. The capitalization of green labels in the California housing market. Reg Sci Urban Econ 2013;47:25-34. doi:10.1016/j.regsciurbeco.2013.07.001.

Kavgic M, Mavrogianni a., Mumovic D, Summerfield a., Stevanovic Z, Djurovic-Petrovic M. A review of bottom-up building stock models for energy consumption in the residential sector. Build Environ 2010;45:168397. doi:10.1016/j.buildenv.2010.01.021.

Kwak SY, Yoo SH, Kwak SJ. Valuing energy-saving measures in residential buildings: A choice experiment study. Energy Policy 2010;38:673-7. doi:10.1016/j.enpol.2009.09.022.

Lancaster KJ. A New Approach to Consumer Theory. J Polit Econ 1966;74:132. doi:10.1086/259131.

Lee $\mathrm{C}-\mathrm{Y}$, Heo H. Estimating willingness to pay for renewable energy in South Korea using the contingent valuation method. Energy Policy 2016;94:150-6. doi:10.1016/j.enpol.2016.03.051.

Lippincott Mercer. Serving the climate-change-conscious consumer. Summary report based on consumer research in the UK and US. 2006.

List JA, Gallet CA. What experimental protocol influence disparities between actual and hypothetical stated values? Environ Resour Econ 2001;20:241-54. doi:10.1023/A:1012791822804.

Liu F, Meyer AS, Hogan JF. Mainstream Building Energy Efficiency Codes in Developing Countries. Global Experiencies and Lessons from Early Adopters. World Bank. Washington D.C.: The International Bank for Reconstruction and Development / The World Bank; 2010. 
Longo A, Markandya A, Petrucci M. The internalization of externalities in the production of electricity: Willingness to pay for the attributes of a policy for renewable energy. Ecol Econ 2008;67:140-52. doi:10.1016/j.ecolecon.2007.12.006.

López-Morales E, Gasic Klett I, Meza Corvalán D. Urbanismo proempresarial en Chile: Políticas y planificación de la producción residencial en el altura en el pericentro del Gran Santiago. Rev INVI 2012;27:75-114.

Marmolejo-Duarte C. La incidencia de la calificación energética sobre los valores residenciales: un análisis para el mercado plurifamiliar en Barcelona. Inf La Construcción 2016;68:e156. doi:10.3989/ic.16.053.

Marmolejo-Duarte C, Bravi M. Does the Energy Label (EL) Matter in the Residential Market? A Stated Preference Analysis in Barcelona. Buildings 2017;7:53. doi:10.3390/buildings7020053.

Marmolejo-Duarte C, García-Hoohghuis A, García-Masiá A. How much does the energy class of our dwellings matter to us? An analysis of the level of understanding of EPCs, willingness to pay and reasons for payment in Barcelona. Rev Hábitat Sustentable 2017;7:54-65. doi:10.22320/07190700.2017.07.01.06.

Ministerio de Vivienda y Urbanismo. Informe Técnico Sistema de Calificación Energética de Viviendas 2017. http://www.calificacionenergetica.cl/media/Informe-Técnico-enero-2017.pdf (accessed October 24, 2017).

Ministerio de Vivienda y Urbanismo. Tomo II: Energía. 2016.

MINVU. Ordenanza General de Urbanismo y Construcciones. Santiago: Ministerio de Vivienda y Urbanismo [Ministry of Housing and Urban Planning]; 2016a.

MINVU. Estándares de Construcción Sustentable para Viviendas de Chile. Tomo II Energía. Santiago: Ministerio de Vivienda y Urbanismo [Ministry of Housing and Urban Planning]; 2016b.

MINVU. Política Nacional de Desarrollo Urbano. Ciudades Sustentables y Calidad de Vida. Santiago: Ministerio de Vivienda y Urbanismo [Ministry of Housing and Urban Planning]; 2014a.

MINVU. NTM 011/2 2014 Anteproyecto - Requisitos y mecanismos de acreditación para acondicionamiento ambiental de las edificaciones. Parte 2: Comportamiento higrotémico. Santiago: Ministerio de Vivienda y Urbanismo [Ministry of Housing and Urban Planning]; 2014b.

Mitchell R, Carson R. Using surveys to value public goods: The Contingent Valuation method. Washington, D.C.: Resources for the Future; 1989.

National Oceanic and Atmospheric Administration. Natural Resource Damage Assessment: Final Rules. Washington, D.C.: 1996.

National Oceanic and Atmospheric Administration. Natural Resource Damage Assessment: Proposed Rules. Washington, D.C.: 1994.

Official Journal of the European Union. Commission Delegated Regulation (EU) No 244/2012 of 16 January 2012 supplementing Directive 2010/31/EU of the European Parliament and of the Council on the energy performance of buildings by establishing a comparative methodology framework for calculating 2012 .

Official Journal of the European Union. Directive 2010/31/EU of the European Parliament and of the Council of 19 May 2010 on the energy performance of buildings (recast) 2010:13-35.

Official Journal of the European Union. Directive 2002/91/EC of the European Parliament and of the Council of 16 December 2002 on the energy performance of buildings 2003:65-71.

Park M, Hagishima A, Tanimoto J, Chun C. Willingness to pay for improvements in environmental performance of residential buildings. Build Environ 2013;60:225-33. doi:10.1016/j.buildenv.2012.10.017.

Pérez-Lombard L, Ortiz J, González R, Maestre IR. A review of benchmarking, rating and labelling concepts within the framework of building energy certification schemes. Energy Build 2009;41:272-8. doi:10.1016/j.enbuild.2008.10.004. 
Portalinmobiliario.com. Tu hogar está aquí. Casas, departamentos en arriendo y venta 2017. http://www.portalinmobiliario.com/ (accessed October 27, 2017).

Riera P. Manual de Valoración Contingente. Madrid: Ministerio de Economía y Hacienda, Instituto de Estudios Fiscales; 1994.

Rioseco R, Tesser C. Cartografía Interactiva de los climas de Chile [en línea]. Inst Geogr Pontif Univ Católica Chile 2017. http://www7.uc.cl/sw_educ/geografia/cartografiainteractiva/ (accessed October 9, 2017).

Romano KR, Dias Bartolomeu Abadio Finco F, Rosenthal A, Vinicius Alves Finco M, Deliza R. Willingness to pay more for value-added pomegranate juice (Punica granatum L.): An open-ended contingent valuation. Food Res Int 2016;89:359-64. doi:10.1016/j.foodres.2016.08.039.

Santin OG. Behavioural patterns and user profiles related to energy consumption for heating. Energy Build 2011;43:2662-72. doi:10.1016/j.enbuild.2011.06.024.

Savage M, Warde A, Ward K. Urban Sociology, Capitalism and Modernity. Second edi. Palgrave Macmillan; 2003

Shi L, Gao Z, Chen X. The cross-price effect on willingness-to-pay estimates in open-ended contingent valuation. Food Policy 2014;46:13-21. doi:10.1016/j.foodpol.2014.01.009.

Sundt S, Rehdanz K. Consumers â€ $€^{\mathrm{TM}}$ willingness to pay for green electricity : A meta-analysis of the literature. Energy Econ 2015;51:1-8. doi:10.1016/j.eneco.2015.06.005.

UNE-EN15459. Energy performance of buildings - Economic evaluation procedure for energy systems in buildings. Brussels: European Committee for Standardization; 2008.

Wu C, Sharma R. Housing submarket classification: The role of spatial contiguity. Appl Geogr 2012;32:746-56. doi:10.1016/j.apgeog.2011.08.011.

Yoshino H, Hong T, Nord N. IEA EBC annex 53: Total energy use in buildings-Analysis and evaluation methods. Energy Build 2017;152:124-36. doi:10.1016/j.enbuild.2017.07.038.

Young W, Hwang K, McDonald S, Oates CJ. Sustainable consumption: Green consumer behaviour when purchasing products. Sustain Dev 2010;18:20-31. doi:10.1002/sd.394.

Zalejska-Jonsson A. Stated WTP and rational WTP: Willingness to pay for green apartments in Sweden. Sustain Cities Soc 2014;13:46-56. doi:10.1016/j.scs.2014.04.007.

Zhang L, Wu Y. Market segmentation and willingness to pay for green electricity among urban residents in China: The case of Jiangsu Province. Energy Policy 2012;51:514-23. doi:10.1016/j.enpol.2012.08.053.

Zhou H, Bukenya JO. Information inefficiency and willingness-to-pay for energy-efficient technology: A stated preference approach for China Energy Label. Energy Policy 2016;91:12-21. doi:10.1016/j.enpol.2015.12.040.

Zoric J, Hrovatin N. Household willingness to pay for green electricity in Slovenia. Energy Policy 2012;47:1807. doi:10.1016/j.enpol.2012.04.055. 